\title{
Genetic and environmental relationships of different measures of individual cheese yield and curd nutrients recovery with coagulation properties of bovine milk
}

\section{A. Cecchinato ${ }^{1}$ and G. Bittante}

Department of Agronomy, Food, Natural Resources, Animals and Environment (DAFNAE), University of Padova, Viale dell'Università 16, 35020 Legnaro (PD), Italy

\begin{abstract}
The aim of this study was to elucidate the relationships between various cheesemaking-related traits, namely the well-known traditional milk coagulation properties (MCP), the new curd firming and syneresis traits, the cheese yield, and the curd nutrient recoveries or whey losses (all measured at the individual level). Data were obtained from 1,167 Brown Swiss cows reared in 85 herds. A 2-L milk sample was collected once from each animal and assessed for 10 phenotypes related to changes in curd firmness $(\mathrm{CF})$ over time, plus 7 cheesemaking traits. The CF-related traits included 4 traditional single-point lactodynamographic properties [rennet coagulation time (RCT, min); time to a $\mathrm{CF}$ of $20 \mathrm{~mm}$, min; and the CF 30 and 45 min after rennet addition ( $\mathrm{a}_{30}$ and $\mathrm{a}_{45}$, respectively)], 4 parameters used to model the $360 \mathrm{CF}$ data recorded over time for each milk sample [the potential asymptotic $\mathrm{CF}$ at infinite time $\left(\mathrm{CF}_{\mathrm{P}}, \mathrm{mm}\right)$; the $\mathrm{CF}$ instant rate constant, $\% \times \mathrm{min}^{-1}$; the syneresis instant rate constant, $\% \times \min ^{-1}$; and the RCT obtained from modeling individual samples], and 2 traits calculated from individual equations [the maximum $\mathrm{CF}\left(\mathrm{CF}_{\max }, \mathrm{mm}\right)$; and the time at $\mathrm{CF}_{\max }$, min]. The cheesemaking traits included 3 cheese yield traits (weights of the fresh curd, curd solids and curd moisture as percent of the weights of the processed milk) and 4 milk nutrient recoveries in the curd (calculated as the percent ratios between a given nutrient in the curd versus that in the processed milk). Bayesian methodology-based multivariate analyses were used to estimate the phenotypic, additive genetic, herd/date, and residual relationships between the aforementioned traits, whereas statistical inferences were based on the marginal posterior distributions of the parameters of concern. The $\mathrm{a}_{45}, \mathrm{CF}_{\mathrm{P}}$, and $\mathrm{CF}_{\max }$ traits were genetically associated with all of the percent cheese yield traits
\end{abstract}

Received March 26, 2015.

Accepted November 11, 2015.

${ }^{1}$ Corresponding author: alessio.cecchinato@unipd.it (the additive genetic correlations varied from 0.752 to 0.855 for $\mathrm{a}_{45} ; 0.496$ to 0.583 for $\mathrm{CF}_{\mathrm{P}}$; and 0.750 to 0.801 for $\mathrm{CF}_{\max }$ ) and the nutrient recovery traits (additive genetic correlations varied from 0.296 to 0.901 for $\mathrm{a}_{45}$; 0.428 to 0.697 for $\mathrm{CF}_{\mathrm{P}}$; and 0.412 to 0.941 for $\mathrm{CF}_{\max }$ ). Moreover, the nutrient recoveries for fat, solids, and energy exhibited large additive genetic correlations with the other coagulation and curd firming traits. In particular, recovery of protein and fat were found to be powerful instruments for understanding the relationships between milk technological properties and cheese quantity or quality. We observed only weak genetic relationships with the milk quality and MCP traits, suggesting that the highly heritable trait of protein recovery should perhaps be included as a genetic index when seeking to improve cheesemaking efficiency at the population level. In contrast, we found that fat recovery exhibited moderate genetic variation and could be improved through the $\mathrm{CF}$ over time traits, especially using those recorded during the late phase of the curd firming process. Moreover, our results demonstrated that the traditional MCP have limited relevance for predicting individual cheese yield. Therefore, their use for this purpose in the dairy industry and breeding programs seems questionable.

Key words: cheese yield, whey losses, milk coagulation, curd firming, genetic correlations

\section{INTRODUCTION}

The cheesemaking process relies not only on the available dairy plants and technology, but also the nutrient contents and technological properties of the processed milk (Law and Tamime, 2010). Cheese yield (CY), which is often expressed as the percentage ratio between the curd produced and the milk processed ( $\left.\mathbf{H C Y}_{\mathbf{C U R D}}\right)$, is a key parameter from both the technological and economic sides of the dairy industry (Emmons, 1993). The economic importance of $\% \mathrm{CY}_{\mathrm{CURD}}$ is substantiated by the observation that cheese production is the most important use of milk in many countries (International Dairy Federation, 2011). 
Several phenotype-level studies have examined the relationships between the final parameters of cheesemaking (cheese yield, nutrients lost in the whey, cheese quality, and so on) and the milk composition (VerdierMetz et al., 2001; Hallén et al., 2010), cow breed (Mistry et al., 2002; Malacarne et al., 2006; Martin et al., 2009), the number of milkings (Martin et al., 2009), the stage of lactation (Kefford et al., 1995), and the rearing and feeding systems (Kefford et al., 1995; Summer et al., 2003). Due to the difficulty and cost of studying CY and its related traits across numerous cheesemakings, especially at the level of each individual cow, very few published studies have examined the genetic parameters of such traits. Othmane et al. (2002a), using a very simplified procedure, estimated that the CY of ovine milk is characterized by a rather low heritability (about one half that of milk yield and one third that of protein content; Othmane et al., 2002b,c). Recently, Bittante et al. (2013a) estimated a much larger heritability for $\% \mathrm{CY}_{\mathrm{CURD}}$ (about twice the heritability of the milk yield) using individual 1,500-mL samples of bovine milk subjected to a model cheesemaking procedure. Moreover, the same authors estimated the genetic parameters (heritability and genetic correlations) of several other CY traits, including that of DM (\% CY $\left.\mathbf{Y}_{\text {SOLIDS }}\right)$, water retained in the curd $\left(\mathbf{\%} \mathbf{C Y} \mathbf{Y}_{\text {WATER }}\right)$, the percentage recovery (REC) of individual milk nutrients in the curd $\left(\mathbf{R E C}_{\mathrm{FAT}}, \mathbf{R E C}_{\text {PROTEIN }}, \mathbf{R E C}_{\text {SOLIDS }}\right.$, and RE$\mathbf{C}_{\text {ENERGY }}$ ), and, conversely, their losses in whey.

For decades, milk samples have most often been characterized with respect to their coagulation properties (MCP; Annibaldi et al., 1977), simultaneously obtained by mimicking the cheesemaking process (i.e., heating, rennet addition, and milk coagulation) for 10 milk samples of $10 \mathrm{~mL}$ each (McMahon and Brown, 1982). Such instruments are unable to estimate $\% \mathrm{CY}_{\mathrm{CURD}}$, but they allow the recording of the rennet coagulation time (RCT, min), the curd firming time $\left(\mathbf{k}_{\mathbf{2 0}}, \mathbf{m i n}\right)$, and the curd firmness (CF) after 30 min from enzyme addition $\left(\mathbf{a}_{\mathbf{3 0}}, \mathrm{mm}\right)$. These instruments are used, in some cases, for milk payment systems (Bittante, 2011).

Many studies have examined the effects of individual cow-level milk quality on MCP in terms of both product-related (milk contents, protein genetic variants, acidity, SCC, and so on) and process-related (cow breed, stage of lactation, feeding, and so on) features. The genetics of the MCP have been studied by several authors, as reviewed by Bittante et al. (2012). The MCP have been considered not only as traits, but also as possible predictors of $\% \mathrm{CY}_{\mathrm{CURD}}$ and its correlated traits. Ikonen et al. (1999) examined Emmental cheese made from herds characterized by good versus poor $\mathrm{MCP}$, and found that the CY for the former were 3.0 and $1.7 \%$ higher for fresh and ripened cheese, respec- tively, and that the fat and protein losses in the whey were lower. However, Ikonen et al. (1999) noted that the milk produced by the 2 groups of farms differed in their casein content, whey protein content, and the proportions of relevant genetic variants. Malacarne et al. (2006) examined Parmigiano Reggiano cheesemaking and found that milk from Brown Swiss cows (which are characterized by very good MCP) yielded $12 \%$ more fresh cheese and lower-fat whey compared with milk from Holstein Friesian cows. Differences in $\% \mathrm{CY}_{\mathrm{CURD}}$ seemed to be attributed mainly to a different casein content of the vat milk.

Recently, Pretto et al. (2013) recorded the milk compositions from 96 vats during Grana Padano cheesemaking in a commercial dairy and used a statistical model that accounted for the milk fat content, protein content, and titratable acidity to show that $\% \mathrm{CY}_{\mathrm{CURD}}$ was significantly improved by an increase in $\mathrm{a}_{30}$. In contrast, Bonfatti et al. (2014) produced 40 experimental model cheeses from milk samples that varied widely in their MCP but had similar fat and casein contents, and concluded that the $\mathrm{MCP}$ did not affect $\% \mathrm{CY}_{\mathrm{CURD}}$ or $\% \mathrm{CY}_{\text {SOLIDS }}$. Notably, these studies were not carried out at the individual cow level, and therefore could not assess the genetic relationships between the MCP and CY. The aims of the present study were to investigate the additive genetic, herd/date, and residual relationships of traditional single-point MCP observations and the new curd firming and syneresis traits with $\mathrm{CY}$ and REC traits.

\section{MATERIALS AND METHODS}

\section{Animals and Milk Sampling}

Milk samples were obtained from a total of 1,167 Brown Swiss cows from 85 herds (a maximum of 15 cows per herd) located in the Alpine province of Trento (Italy); milk samples were obtained once per cow during the evening milking. Within a given day, only 1 herd was sampled and the herd sampling was distributed through a full year (1-2 herds per week).

The present study is part of the Cowability-Cowplus projects. Detailed descriptions of the sampling procedure may be found in Cipolat-Gotet et al. (2012), whereas the production environment is described in Sturaro et al. (2013). Briefly, the collected samples (without preservative) were immediately refrigerated at $4^{\circ} \mathrm{C}$ and transferred to the Cheese-Making Laboratory of the Department of Agronomy, Food, Natural Resources, Animals and Environment of the University of Padova (Legnaro, Padova, Italy).

Data on the cows and herds were provided by the Superbrown Consortium of Bolzano and Trento (Italy), 
and pedigree information was supplied by the Italian Brown Swiss Cattle Breeders Association (ANARB, Verona, Italy). We included cows with phenotypic records available for the investigated traits and all known ancestors. Each sampled cow had at least 4 generations of known ancestors, and the pedigree file included 8,845 animals. The number of sires was 1,326; of these, 264 had progeny with records in the data set (each sire having between 2 and 80 daughters).

\section{CY-Related Phenotypes}

Traditional MCP. Milk coagulation properties were obtained using a mechanical lactodynamograph (Formagraph; Foss Electric A/S, Hillerød, Denmark), as described by Cipolat-Gotet et al. (2012). Each individual milk sample $(10 \mathrm{~mL})$ was heated to $35^{\circ} \mathrm{C}$ and mixed with $200 \mu \mathrm{L}$ of a $1.2 \%$ (wt/vol) rennet solution (Hansen Standard 215, 215 international milk clotting units $/ \mathrm{mL}$; with $80 \pm 5 \%$ chymosin and $20 \pm 5 \%$ pepsin; Pacovis Amrein AG, Bern, Switzerland) diluted in distilled water to yield 0.051 international milk clotting units/mL. The extended (90-min) observation period began immediately after rennet addition. The instrument recorded the width (in millimeters) of the oscillatory graph every $15 \mathrm{~s}$ during testing and directly provided RCT ( $\mathrm{min}$ ), defined as the time from enzyme addition to the gelation of the milk; $\mathrm{k}_{20}(\mathrm{~min})$, defined as the time from gelation to the time at which the width of the graph attained $20 \mathrm{~mm}$; and the widths of the graph at $30\left(\mathbf{a}_{30}, \mathrm{~mm}\right), 45\left(\mathbf{a}_{45}, \mathrm{~mm}\right)$, and $60 \mathrm{~min}$ $\left(\mathbf{a}_{60}, \mathrm{~mm}\right)$ from rennet addition (measuring the extent of $\mathrm{CF}$ ).

Modeling the CF of Individual Milk Samples. Curd firmness was measured every $15 \mathrm{~s}$ for $90 \mathrm{~min}$, for a total of 360 recorded $\mathrm{CF}$ values per sample. The data were analyzed using the 4-parameter equation proposed by Bittante et al. (2013b) for modeling an extended observation of $\mathrm{CF}$ derived by the 3-parameter equation (Bittante, 2011). The 4-parameter model is given as follows:

$$
\mathrm{CF}_{\mathrm{t}}=\mathrm{CF}_{\mathrm{p}} \times\left[1-e^{-\mathrm{k}_{\mathrm{CF}} \times\left(\mathrm{t}-\mathrm{RCT}_{\mathrm{eq}}\right)}\right] \times e^{-\mathrm{k}_{\mathrm{SR} \times\left(\mathrm{t}-\mathrm{RCT}_{\mathrm{eq}}\right)}},
$$

where $\mathbf{C F}_{\mathbf{t}}$ is the curd firmness at time $\mathrm{t}(\mathrm{mm}) ; \mathbf{C F}_{\mathbf{P}}$ is the asymptotic potential maximum value of $\mathrm{CF}$ $(\mathrm{mm}) ; \mathbf{k}_{\mathrm{CF}}$ is the curd-firming instant rate constant $\left(\% \times \min ^{-1}\right) ; \mathbf{k}_{\mathrm{SR}}$ is the curd syneresis instant rate constant $\left(\% \times \mathrm{min}^{-1}\right)$; and $\mathbf{R C T}$ eq is the rennet coagulation time ( $\mathrm{min})$. Curd firmness represents a function of the maximum asymptotic $\mathrm{CF}\left(\mathrm{CF}_{\mathrm{P}}\right)$, the processes of curd firming and syneresis (represented by the 2 rate constants), and an initial lag phase (represented by $\left.\mathrm{RCT}_{\mathrm{eq}}\right)$. The first constant, $\mathrm{k}_{\mathrm{CF}}$, is assumed to increase $\mathrm{CF}$ toward its potential asymptotic value $\left(\mathrm{CF}_{\mathrm{P}}\right)$, whereas $\mathrm{k}_{\mathrm{SR}}$ is assumed to reduce the $\mathrm{CF}$ toward zero due to the expulsion of whey from the curd and the free floating of the curd. After gelation, $\mathrm{k}_{\mathrm{CF}}$ prevails on $\mathrm{k}_{\mathrm{SR}}$ and $\mathrm{CF}$ increases to a maximum value that is achieved when the 2 opposing phenomena are equal. Afterward, the curve begins to descend toward a null asymptotic value (Figure 1). This allows the calculation of 2 other traits for the maximum CF (MCF): $\mathbf{C F}_{\max }$ is the maximum value reached by the $\mathrm{CF}_{\mathrm{t}}$ function $(\mathrm{mm})$; and $\mathbf{t}_{\text {max }}$ is the time at which $\mathrm{CF}_{\max }$ is achieved (min). This model uses all available information to estimate the 4 parameters; these are not single-point measurements and they are therefore less interdependent than the traditional MCP. The $\mathrm{CF}_{\mathrm{t}}$ observations available for each subsample were fitted with curvilinear regressions using the nonlinear procedure (PROC NLIN) of SAS (SAS Institute Inc., Cary, NC). The parameters of each individual equation were estimated by employing the Marquardt iterative method (350 iterations and a $10^{-5}$ level of convergence).

Model Cheesemaking Procedure. All samples were processed within $20 \mathrm{~h}$ after collection. Individual milk samples were analyzed for the fat, protein, and casein percentages using a MilkoScan FT6000 (Foss Electric A/S). The cheesemaking procedure, which was based on the conditions frequently used to produce

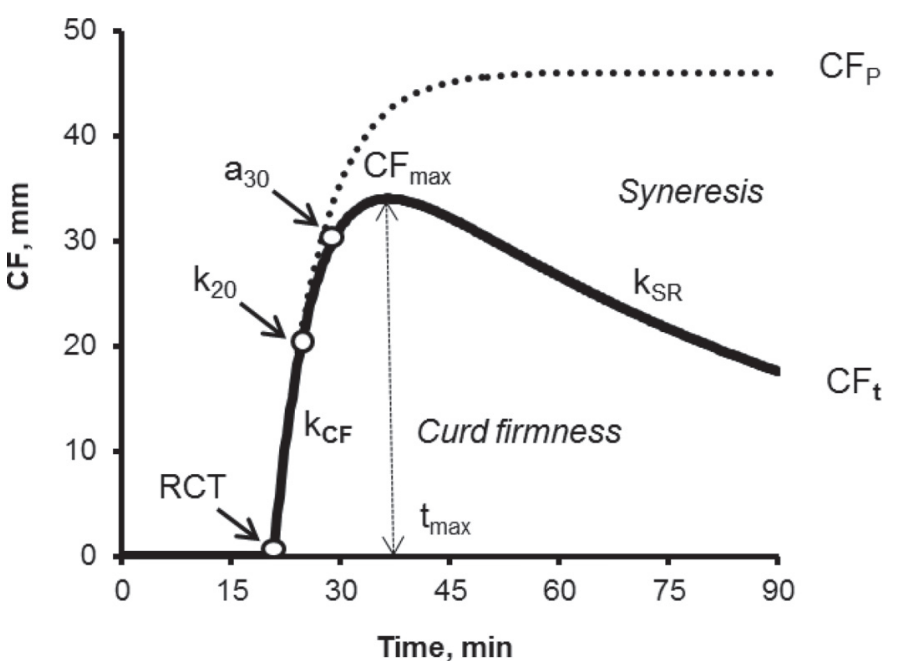

Figure 1. Modeling prolonged observations of curd firmness (CF) at time $\mathrm{t}(\mathrm{CFt}) . \mathrm{RCT}=$ rennet coagulation time; $\mathrm{k}_{20}=$ curd-firming time of samples reaching $20 \mathrm{~mm}$ of firmness within $45 \mathrm{~min}$ from enzyme addition; $\mathrm{a}_{30}=$ curd firmness at $30 \mathrm{~min}$ after enzyme addition; $\mathrm{CFP}=$ potential asymptotical $\mathrm{CF}$ in absence of syneresis; $\mathrm{k}_{\mathrm{CF}}=$ curd firming instant rate constant; $\mathrm{k}_{\mathrm{SR}}=$ syneresis instant rate constant and representation of maximum $\mathrm{CF}$ traits $(\mathrm{MCF}): \mathrm{CF}_{\max }=$ maximum $\mathrm{CF}_{\mathrm{t}}$ value; $\mathrm{t}_{\max }=$ time at $\mathrm{CF}_{\max }$; modified from Bittante et al. (2012) with permission. 
short-ripened cheese, was performed as previously described in detail (Cipolat-Gotet et al., 2013). Briefly, $1,500 \mathrm{~mL}$ of milk was heated to $35^{\circ} \mathrm{C}$ in a stainless steel micro-vat; it was then supplemented with thermophilic starter culture, mixed with rennet, and allowed to coagulate for a controlled period. The resulting curd was individually removed from each vat and then cut, drained, shaped into a wheel, pressed, salted, weighed, sampled, and analyzed. The whey was collected from each vat and weighed, sampled, and analyzed. All of the processed milk samples coagulated within a standard testing time and yielded a model cheese.

CY Trait Analysis. All of the measured traits were based on the weights (W, g) and chemical compositions of the milk and whey. The energy of the curd $\left(\mathrm{kJ} \times \mathrm{g}^{-1}\right)$ was estimated as the difference between the energies of the milk and whey, which was calculated as described by the NRC (2001). The following traits were measured:

(1) $\% \mathrm{CY}_{\text {CURD }}$ is the percentage cheese yield ( $\mathrm{W}$ of curd $\times 100 / \mathrm{W}$ of milk);

(2) $\% \mathrm{CY}_{\text {SOLIDS }}$ is the percentage TS cheese yield [(W of milk TS $-\mathrm{W}$ of whey TS) $\times 100 / \mathrm{W}$ of milk];

(3) $\% \mathrm{CY}_{\text {WATER }}$ is the percentage of water retained in the cheese [( $\mathrm{W}$ of milk water $-\mathrm{W}$ of whey water $)$ $\times 100 / \mathrm{W}$ of milk];

(4) $\mathrm{REC}_{\mathrm{FAT}}(\%)$ is the fat $(\mathrm{F})$ recovery $[(\mathrm{W}$ of milk $\mathrm{F}-\mathrm{W}$ of whey $\mathrm{F}) \times 100 / \mathrm{W}$ of milk F];

(5) $\mathrm{REC}_{\text {PROTEIN }}(\%)$ is the protein $(\mathrm{P})$ recovery $[(\mathrm{W}$ of milk $\mathrm{P}-\mathrm{W}$ of whey $\mathrm{P}) \times 100 / \mathrm{W}$ of milk $\mathrm{P}$;

(6) $\mathrm{REC}_{\text {SOLIDS }}(\%)$ is the TS recovery $[(\mathrm{W}$ of milk TS $-\mathrm{W}$ of whey TS $\times 100 / \mathrm{W}$ of milk TS]; and

(7) $\mathrm{REC}_{\text {ENERGY }}(\%)$ is the energy recovery [(milk energy - whey energy) $\times 100 /$ milk energy].

Figure 2 shows a simplified scheme depicting the roles of the studied technical traits (REC and CY) in explaining the productions of cheese and whey from the milk contents.

\section{Genetic Analysis}

The (co)variance components for the $\mathrm{CY}$ and $\mathrm{REC}$ measures and the $\mathrm{MCP}, \mathrm{CF}_{\mathrm{t}}$ parameters, and $\mathrm{MCF}$ traits were estimated through bivariate analyses and linear models. The general model assumed for the former traits was

$$
\mathrm{y}_{i j k l}=\mu+\mathrm{DIM}_{i}+\text { Parity }_{j}+\mathrm{h}_{k}+\mathrm{a}_{l}+\varepsilon_{i j k l},
$$

where $\mathrm{y}_{i j k l}$ is the phenotypic record for the analyzed trait; $\mathrm{DIM}_{i}$ is the effect of the $i$ th class of DIM $(i=1$ to $11 ; 30 \mathrm{~d}$ for each class, with class 1 being $<30 \mathrm{~d}$ and class 10 being $>300 \mathrm{~d}$ ); Parity $_{j}$ is the effect of the $j$ th parity of the cow ( $j=1$ to 5 or more); $\mathrm{h}_{k}$ is the effect of the $k$ th herd/date $(k=1$ to 85$) ; \mathrm{a}_{l}$ is the additive genetic effect of individual $l$; and $\varepsilon_{i j k l}$ is the residual of the model. The vats or water baths (15 levels) and the renneting meter sensor of the lactodynamograph (10 levels) were considered as additional systematic effects for the CY and REC as well as milk coagulation and CF traits, respectively, as described by Bittante et al. (2013a) and Cecchinato et al. (2013).

\section{Bayesian Inference}

The (co)variance components and related parameters were estimated using a Bayesian approach and Markovchain Monte Carlo methods (Sorensen and Gianola, 2002). All traits were taken as continuous variables, and their values were assumed to be sampled from the following multivariate normal distribution:

$\left[\begin{array}{l}\mathbf{y}_{1} \\ \mathbf{y}_{2}\end{array}\right] \mid \mathbf{b}_{1}, \mathbf{b}_{2}, \mathbf{h}_{1}, \mathbf{h}_{2}, \mathbf{a}_{1}, \mathbf{a}_{2}, \mathbf{R} \sim N\left(\mathbf{X}\left[\begin{array}{l}\mathbf{b}_{1} \\ \mathbf{b}_{2}\end{array}\right]+\mathbf{Z}_{1}\left[\begin{array}{l}\mathbf{h}_{1} \\ \mathbf{h}_{2}\end{array}\right]+\mathbf{Z}_{2}\left[\begin{array}{l}\mathbf{a}_{1} \\ \mathbf{a}_{2}\end{array}\right], \mathbf{R}\right)$

in which $\mathbf{b}_{1}$ and $\mathbf{b}_{2}$ are random vectors that include the effects of DIM and parity; $\mathbf{a}_{1}$ and $\mathbf{a}_{2}$ are vectors of individual additive genetic effects; $\mathbf{h}_{1}$ and $\mathbf{h}_{2}$ are vectors of herd/date effects; $\mathbf{X}, \mathbf{Z}_{1}$, and $\mathbf{Z}_{2}$ are known incidence matrices; and $\mathbf{R}$ is the residual (co)variance matrix. Between traits, the additive, herd/date, and residual effects were assumed to be correlated. When we sorted records by individual and within-individual traits, the residual (co)variance matrix could be written as $\mathbf{R}_{0} \otimes$ $\mathbf{I}_{\mathbf{n}}$, where $\mathbf{R}_{0}$ is the $2 \times 2$ residual (co)variance matrix between the analyzed traits and $\mathbf{I}_{\mathbf{n}}$ is an identity matrix of the appropriate order. Bounded uniform priors were used to represent vague previous knowledge of the distributions of $\mathbf{b}_{1}$ and $\mathbf{b}_{2}$. Prior knowledge concerning the additive and herd/date effects was represented by assuming that they were normally distributed conditional on the associated (co)variance components, as follows:

$$
\begin{aligned}
& {\left[\begin{array}{l}
\mathbf{a}_{1} \\
\mathbf{a}_{2}
\end{array}\right] \mid \mathbf{G} \sim N(0, \mathbf{G})} \\
& {\left[\begin{array}{l}
\mathbf{h}_{1} \\
\mathbf{h}_{2}
\end{array}\right] \mid \mathbf{H} \sim N(0, \mathbf{H}),}
\end{aligned}
$$

where $\mathbf{0}$ is a vector of zeros; $\mathbf{G}$ is the genetic (co)variance matrix; and $\mathbf{H}$ is the (co)variance matrix of herd effects. When we sorted the data by individual (as described above), we could write matrices $\mathbf{G}$ and $\mathbf{H}$ as $\mathbf{G}_{0}$ $\otimes \mathbf{A}$ and $\mathbf{H}_{0} \otimes \mathbf{I}_{\mathrm{s}}$, respectively, where $\mathbf{G}_{0}$ and $\mathbf{H}_{0}$ are the $2 \times 2$ genetic and herd/date (co)variance matrices, 
respectively; $\mathbf{A}$ is the known additive genetic relationship matrix; and $\mathbf{I}_{\mathbf{s}}$ is an identity matrix of the same order as the number of herd/date effect levels. Bounded uniform priors were used for the components of the (co) variance matrices, $\mathbf{R}_{0}, \mathbf{G}_{0}$, and $\mathbf{H}_{0}$

Marginal posterior distributions of unknown parameters were estimated by performing numerical integration through the Gibbs sampler (Gelfand and Smith,
1990), as implemented in the TM program (http://snp. toulouse.inra.fr/ alegarra). The lengths of the chain and burn-in period were assessed by visual inspection of trace plots, and by the diagnostic tests described by Geweke (1992) and Gelman and Rubin (1992). After a preliminary run, we decided to construct a single chain consisting of 850,000 iterations and discard the first 50,000 iterations as a very conservative burn-in. Subse-

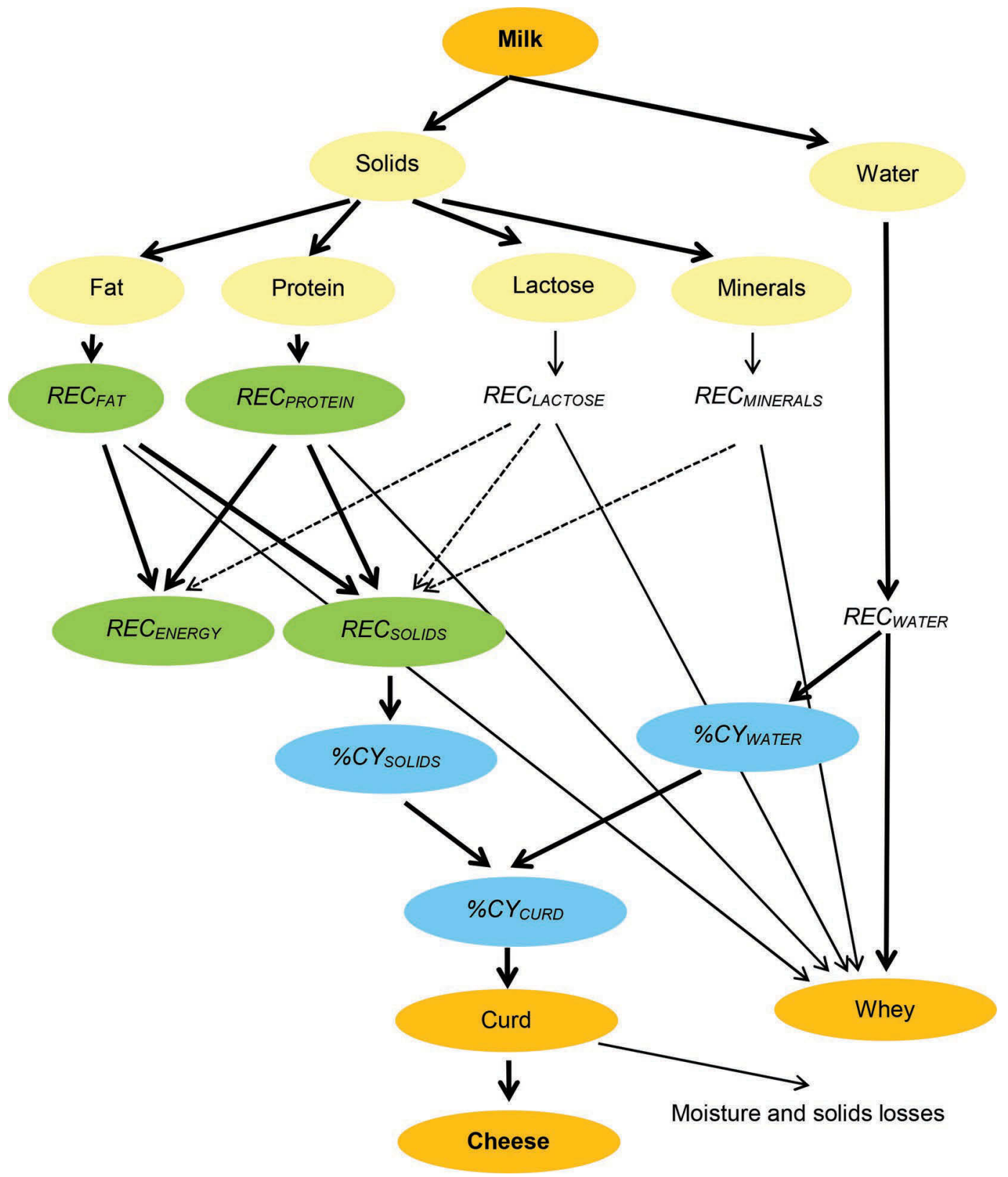

Figure 2. Role of technological traits (recovery in green and cheese yield in blue) in explaining the cheese and whey production from the milk contents $\left(\mathrm{REC}_{\mathrm{PROTEIN}}=\right.$ protein of the curd as percentage of the protein of the milk processed; $\mathrm{REC}_{\mathrm{FAT}}=$ fat of the curd as percentage of the fat of the milk processed; $\mathrm{REC}_{\mathrm{SOLIDS}}=$ solids of the curd as percentage of the solids of the milk processed; $\mathrm{REC}_{\mathrm{ENERGY}}=$ energy of the curd as percentage of energy of the milk processed; $\% \mathrm{CY}_{\mathrm{CURD}}=$ weight of fresh curd as percentage of weight of milk processed; $\% \mathrm{CY}$ SOLIDS $=$ weight of curd solids as percentage of weight of milk processed; $\% \mathrm{CY}_{\text {WATER }}=$ weight of water curd as percentage of weight of milk processed). Color version available online. 
quently, 1 in every 200 successive samples was retained to store draws that were more loosely correlated. Thus, 4,000 samples were used to determine the posterior distributions of the unknown parameters. The lower and upper bounds of the highest $95 \%$ probability density regions for the parameters of interest were obtained from the estimated marginal densities. The posterior median was used as the point for all parameters. Autocorrelations between samples and estimates of the Monte Carlo Standard Error (Geyer, 1992) were calculated.

The additive genetic correlations $\left(r_{a}\right)$ were computed as

$$
r_{a}=\frac{\sigma_{a 1, a 2}}{\sigma_{a 1} \cdot \sigma_{a 2}}
$$

where $\sigma_{a 1, a 2}$ was the additive genetic covariance between traits 1 and 2, and $\sigma_{a 1}$ and $\sigma_{a 2}$ were the additive genetic standard deviations for traits 1 and 2, respectively.

The herd/date correlations $\left(r_{h}\right)$ were computed as:

$$
r_{h}=\frac{\sigma_{h 1, h 2}}{\sigma_{h 1} \cdot \sigma_{h 2}},
$$

where $\sigma_{h 1, h 2}$ was the herd/date covariance between traits 1 and 2 , and $\sigma_{h 1}$ and $\sigma_{h 2}$ were the herd/date standard deviations for traits 1 and 2, respectively.

The residual correlations $\left(r_{e}\right)$ were computed as:

$$
r_{e}=\frac{\sigma_{e 1, e 2}}{\sigma_{e 1} \cdot \sigma_{e 2}},
$$

where $\sigma_{e 1, e 2}$ was the residual covariance between traits 1 and 2 , and $\sigma_{e 1}$ and $\sigma_{e 2}$ were the residual standard deviations for traits 1 and 2, respectively.

The phenotypic correlations $\left(r_{p}\right)$ were computed as:

$$
r_{p}=\frac{\sigma_{p 1, p 2}}{\sigma_{p 1} \cdot \sigma_{p 2}}
$$

where $\sigma_{p 1, p 2}$ is the phenotypic covariance between traits 1 and 2 ; and $\sigma_{p 1}$ and $\sigma_{p 2}$ are the phenotypic standard deviations of for traits 1 and 2, respectively.

\section{RESULTS}

\section{Descriptive Statistics and Variance Components}

Descriptive statistics for the studied traits are presented in Table 1. All of the new phenotypes related to the $\mathrm{CY}, \mathrm{REC}, \mathrm{CF}_{\mathrm{t}}$, and $\mathrm{MCF}$ traits show appreciable levels of variation. The additive genetic contributions differed among the traits, ranging from small values for
$\mathrm{REC}_{\mathrm{FAT}}$ and the $\mathrm{CF}$ traits that characterize the final part of the $\mathrm{CF}_{\mathrm{t}}$ model $\left(\mathrm{a}_{45}, \mathrm{CF}_{\mathrm{P}}\right.$ and $\left.\mathrm{k}_{\mathrm{SR}}\right)$ to a large value for $\mathrm{REC}_{\text {Protein. }}$ The herd/date effect also differed across the traits, varying from the small values of the MCP, $\mathrm{CF}_{\mathrm{t}}$ and $\mathrm{MCF}$ traits to the intermediate values of the $\mathrm{CY}$ and REC traits. Because of this, the residual variation was lower than $50 \%$ of the total phenotypic variance for only $\mathrm{REC}_{\text {PROTEIN }}$, whereas it was close to $80 \%$ for $\mathrm{CF}_{\mathrm{P}}$ and $\mathrm{k}_{\mathrm{SR}}$.

\section{Relationships of Traditional MCP, $C F_{t}$, and MCF Traits with CY}

Table 2 shows the phenotypic, additive genetic, herd/ date, and residual relationships between the traditional MCP and the CY traits, and Table 3 shows the corresponding correlations between the $\mathrm{CF}_{\mathrm{t}}$ parameters or MCF and the CY traits.

The first set of additive genetic correlations was characterized by large estimated variabilities, as reflected by the lower and upper bounds of the $95 \%$ highest posterior density regions. For the MCP, the strongest relationship with CY was exhibited by $\mathrm{a}_{45}$, which was strongly and positively associated with $\% \mathrm{CY}_{\mathrm{CURD}}$ and its components, $\% \mathrm{CY}_{\text {SOLIDS }}$ and $\% \mathrm{CY}_{\text {WATER }}$. The $\mathrm{a}_{30}$ trait showed a much lower and more variable genetic correlation with the CY compared with $\mathrm{a}_{45}$, whereas $\mathrm{k}_{20}$ tended to be negatively (favorably) correlated with the CY traits. Rennet coagulation time showed almost null genetic correlations with the CY traits. Furthermore, the parameters of the individual equations depicting the pattern of $\mathrm{CF}$ over time showed the greatest (positive) associations between the $\mathrm{CY}$ and the maximum and potential $\mathrm{CF}$ parameters $\left(\mathrm{CF}_{\max }\right.$ and, with a great variation of the estimates, the $\mathrm{CF}_{\mathrm{P}}$ equation parameter; Table 3). The other parameters $\left(\mathrm{RCT}_{\mathrm{eq}}, \mathrm{k}_{\mathrm{CF}}\right.$ and $\left.\mathrm{k}_{\mathrm{SR}}\right)$ and $t_{\max }$ showed little or no genetic relationship with the $3 \mathrm{CY}$ traits.

The herd/date correlations were very variable; their average estimates were lower than the genetic ones (Tables 2 and 3) and the herd/date-level correlations of a given MCP with the $3 \mathrm{CY}$ were less homogeneous and sometimes opposite in sign. Rennet coagulation time tended to be correlated positively (unfavorably) with $\% \mathrm{CY}_{\text {CURD }}$ and $\% \mathrm{CY}_{\text {SOLIDS }}$. The $\mathrm{k}_{20}$ trait was correlated negatively (favorably) with $\% \mathrm{CY}_{\text {SOLIDS }}$ and tended to be positively correlated with $\% \mathrm{CY}_{\text {WATER }}$, but failed to show any significant correlation with $\% \mathrm{CY}_{\mathrm{CURD}}$. The $\mathrm{a}_{30}$ trait presented almost null correlations with the 3 $\mathrm{CY}$; its pattern resembled that of $\mathrm{a}_{45}$, except that the former was positively correlated with $\% \mathrm{CY}_{\text {SOLIDS }}$. The new coagulation and curd-firming phenotypes showed some similarities with the traditional MCP. As expected, the patterns of $\mathrm{RCT}_{\text {eq }}$ and $\mathrm{RCT}$ were similar. 
Table 1. Descriptive statistics and contribution of additive genetic $\left(\sigma_{a}^{2}\right)$, herd/date $\left(\sigma_{h}^{2}\right)$, and residual variances $\left(\sigma_{e}^{2}\right)$ on phenotypic total variance of percentage cheese yield, nutrient recoveries, traditional milk coagulation properties $(\mathrm{MCP})$, curd firming $\left(\mathrm{CF}_{\mathrm{t}}\right)$ model parameters, and maximum curd-firmness traits ${ }^{1}$

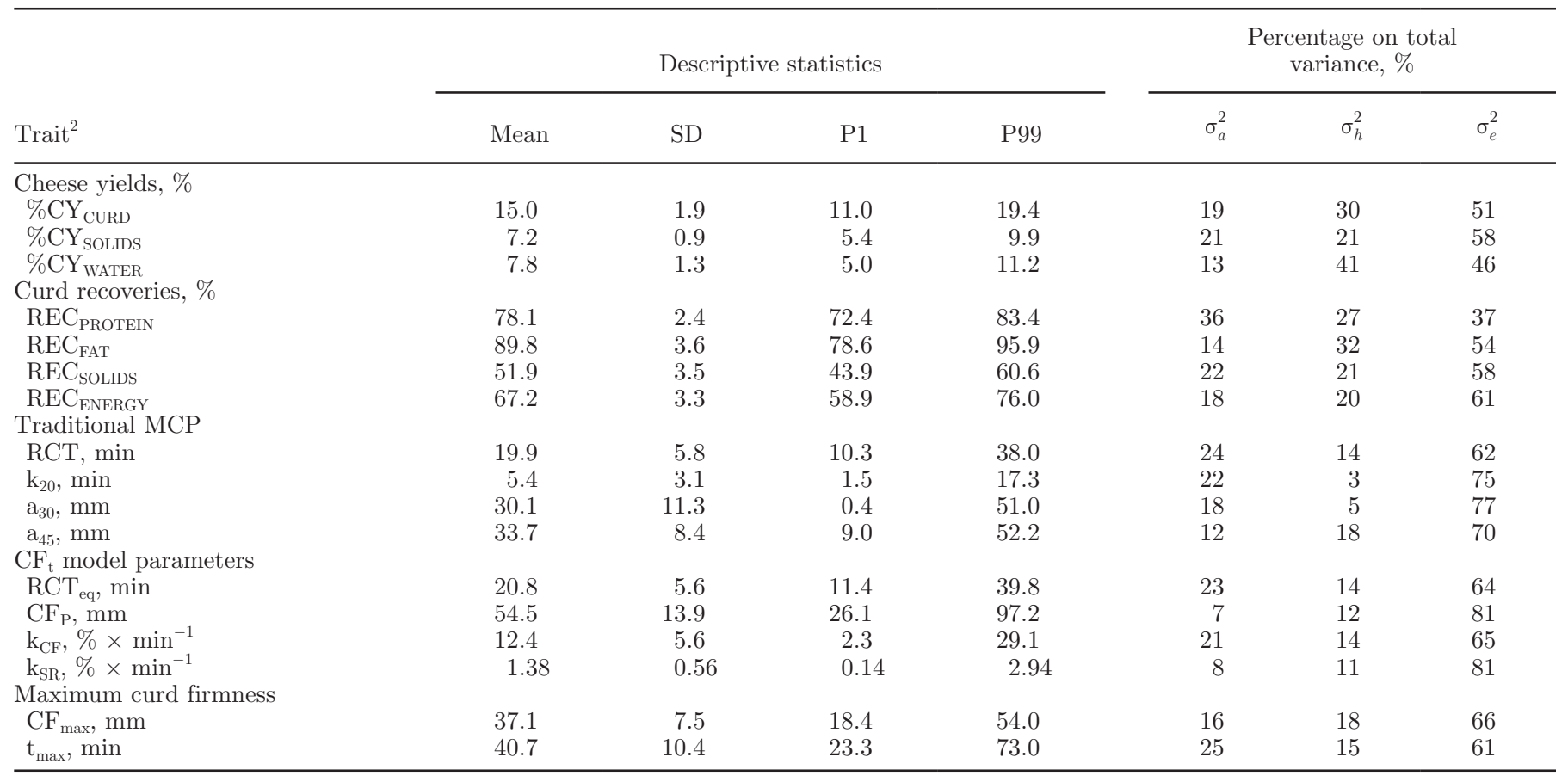

${ }^{1} \mathrm{P} 1=1$ st percentile; $\mathrm{P} 99=99$ th percentile.

${ }^{2} \mathrm{RCT}=$ rennet coagulation time of samples coagulating within $45 \mathrm{~min}$ from enzyme addition; $\mathrm{k}_{20}=$ curd-firming time of samples reaching 20 $\mathrm{mm}$ of firmness within $45 \mathrm{~min}$ from enzyme addition; $\mathrm{a}_{30}=$ curd firmness at 30 min after enzyme addition; $\mathrm{RCT}_{\mathrm{eq}}=$ rennet coagulation time estimated using the $\mathrm{CF}_{\mathrm{t}}$ equation; $\mathrm{CF}_{\mathrm{P}}=$ asymptotic potential curd firmness; $\mathrm{k}_{\mathrm{CF}}=$ curd firming instant rate constant; $\mathrm{k}_{\mathrm{SR}}=$ syneresis instant rate constant; $\mathrm{CF}_{\max }=$ maximum curd firmness achieved within $45 \mathrm{~min} ; \mathrm{t}_{\max }=$ time at achievement of $\mathrm{CF}_{\max } ; \%_{\mathrm{CY}} \mathrm{CURD}=$ weight of fresh curd as percentage of weight of milk processed; $\% \mathrm{CY}_{\text {SOLIDS }}=$ weight of curd solids as percentage of weight of milk processed; $\% \mathrm{CY}$ WATER $=$ weight of water curd as percentage of weight of milk processed; $\mathrm{REC}_{\text {PRотеIN }}=$ protein of the curd as percentage of the protein of the milk processed; $\mathrm{REC}_{\mathrm{FAT}}=$ fat of the curd as percentage of the fat of the milk processed; $\mathrm{REC}_{\mathrm{SOLIDS}}=$ solids of the curd as percentage of the solids of the milk processed; $\mathrm{REC}_{\mathrm{ENERGY}}=$ energy of the curd as percentage of energy of the milk processed.

We also observed similarities in the patterns of $\mathrm{CF}_{\max }$ and $\mathrm{a}_{45}$ (positive correlations with $\% \mathrm{CY}_{\text {SOLIDS }}$ ) and the other traits (small correlations), except that the herd/ date-level $\mathrm{CF}_{\mathrm{P}}$ was positively correlated with the $3 \mathrm{CY}$ traits (high-level correlation with \% $\mathrm{CY}_{\text {SOLIDS, almost }}$ null with $\% \mathrm{CY}_{\mathrm{WATER}}$, and intermediate with the resulting $\left.\% \mathrm{CY}_{\mathrm{CURD}}\right)$.

The estimated residual correlations showed less variability than their genetic and herd/date-level counterparts (Tables 2 and 3). The correlations between the traditional $\mathrm{MCP}$ and the $\mathrm{CY}$ traits had the following characteristics: they all fell (in absolute value) between 0.201 to 0.368 ; their signs were always favorable (negative for RCT and $\mathrm{k}_{20}$ and positive for $\mathrm{a}_{30}$ and $\mathrm{a}_{45}$ ); and they were homogeneous among the $3 \mathrm{CY}$ traits, having the same signs and similar values with respect to $\% \mathrm{CY}_{\text {CURD }}, \% \mathrm{CY}_{\text {SOLIDS }}$, and $\% \mathrm{CY}_{\text {WATER }}$. Among the $\mathrm{CF}_{\mathrm{t}}$ parameters, $\mathrm{RCT}_{\mathrm{eq}}$ was similar to $\mathrm{RCT}$ and $\mathrm{k}_{\mathrm{CF}}$ was similar to $\mathrm{k}_{20}$ (with the opposite sign), whereas $\mathrm{CF}_{\mathrm{P}}$ and $\mathrm{k}_{\mathrm{SR}}$ showed very low correlations with the CY. Among all of the traits related to coagulation, curd firming and syneresis, $\mathrm{CF}_{\max }$ showed the greatest residual correlations with the $\mathrm{CY}$ (especially with $\% \mathrm{CY}_{\mathrm{CURD}}$ ), whereas $t_{\max }$ tended to present small negative correlations with the CY parameters.

The estimated phenotypic correlations between the coagulation, curd firming, and syneresis traits on one side and the $3 \mathrm{CY}$ traits on the other side (Tables 2 and 3) were much less variable than the estimates for the genetic, herd/date, and residual components, but resembled the residual correlations (being the residual variance the mayor component of phenotypic variance for all the traits considered). The absolute values of the correlations ranged from 0.107 to 0.345 for the $\mathrm{MCP}$ and $\mathrm{CF}_{\mathrm{t}}$ parameters (except for $\mathrm{k}_{\mathrm{SR}}$, which was almost null), the signs were all favorable (negative for $\mathrm{RCT}, \mathrm{RCT}_{\mathrm{eq}}$ and $\mathrm{k}_{20}$, but positive for $\mathrm{a}_{30}, \mathrm{a}_{45}, \mathrm{CF}_{\mathrm{P}}$ and $\mathrm{k}_{\mathrm{CF}}$ ), and the values were homogeneous among the 3 $\mathrm{CY}$ traits. Again, $\mathrm{CF}_{\max }$ showed the highest (positive) correlations with the CY (especially with $\% \mathrm{CY}_{\text {SOLIDS }}$ ), 
Table 2. Features of the marginal posterior density of phenotypic $\left(r_{p}\right)$, additive genetic $\left(r_{a}\right)$, herd/date $\left(r_{h}\right)$, and residual $\left(r_{e}\right)$ correlations between individual percentage cheese yield (weight of fresh curd, curd solids, and curd water as percentage of weight of milk processed) and traditional milk coagulation properties ${ }^{1}$

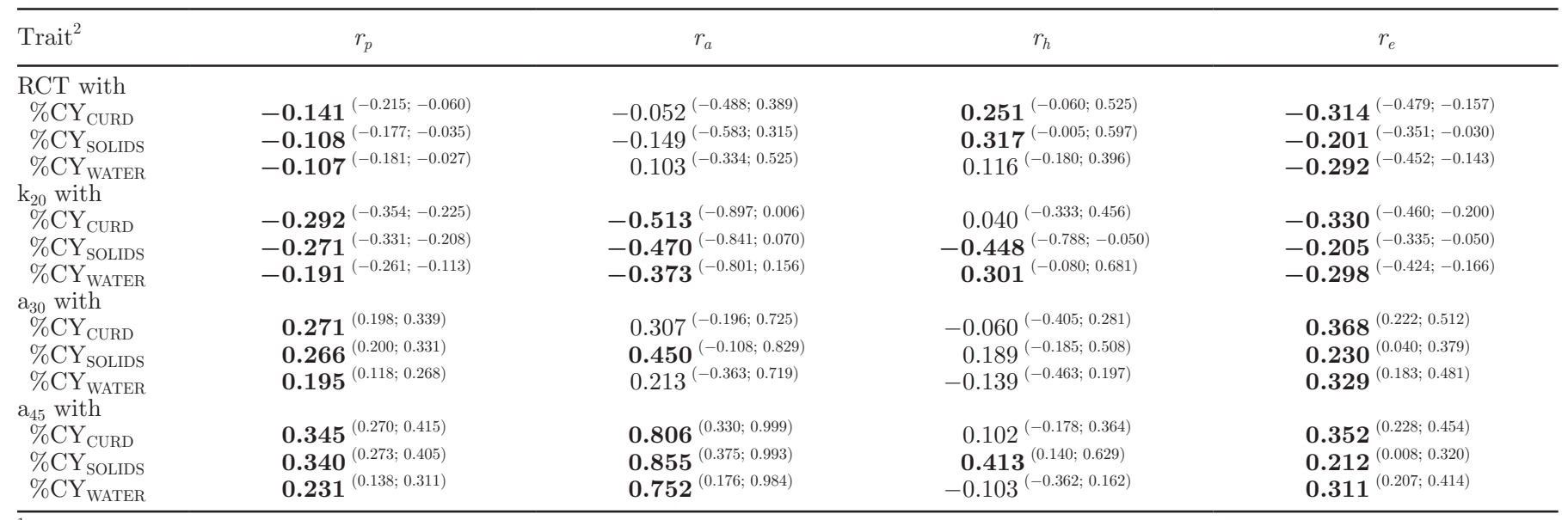

${ }^{1}$ Estimates are the median of the marginal posterior density of the parameter (lower and upper bounds of the $95 \%$ highest posterior density region in parentheses); bold indicates correlations with $\geq 90 \%$ of posterior probability accumulated above 0 (positive estimates) or below 0 (negative estimates).

${ }^{2} \% \mathrm{CY}_{\mathrm{CURD}}=$ weight of fresh curd as percentage of weight of milk processed; $\% \mathrm{CY}_{\text {SOLIDS }}=$ weight of curd solids as percentage of weight of milk processed; \% $\mathrm{CY}_{\text {WATER }}=$ weight of water curd as percentage of weight of milk processed; RCT = rennet coagulation time of samples coagulating within $45 \mathrm{~min}$ from enzyme addition; $\mathrm{k}_{20}=$ curd-firming time of samples reaching $20 \mathrm{~mm}$ of firmness within 45 min from enzyme addition; $\mathrm{a}_{30}$ $=$ curd firmness at $30 \mathrm{~min}$ after enzyme addition; $\mathrm{a}_{45}=$ curd firmness at $45 \mathrm{~min}$ after enzyme addition.

Table 3. Features of the marginal posterior density of phenotypic $\left(r_{p}\right)$, additive genetic $\left(r_{a}\right)$, herd/date $\left(r_{h}\right)$, and residual $\left(r_{e}\right)$ correlations between individual percentage cheese yield (weight of fresh curd, curd solids, and curd water as percentage of weight of milk processed) and curd firming model parameters and derived maximum curd-firmness traits ${ }^{1}$

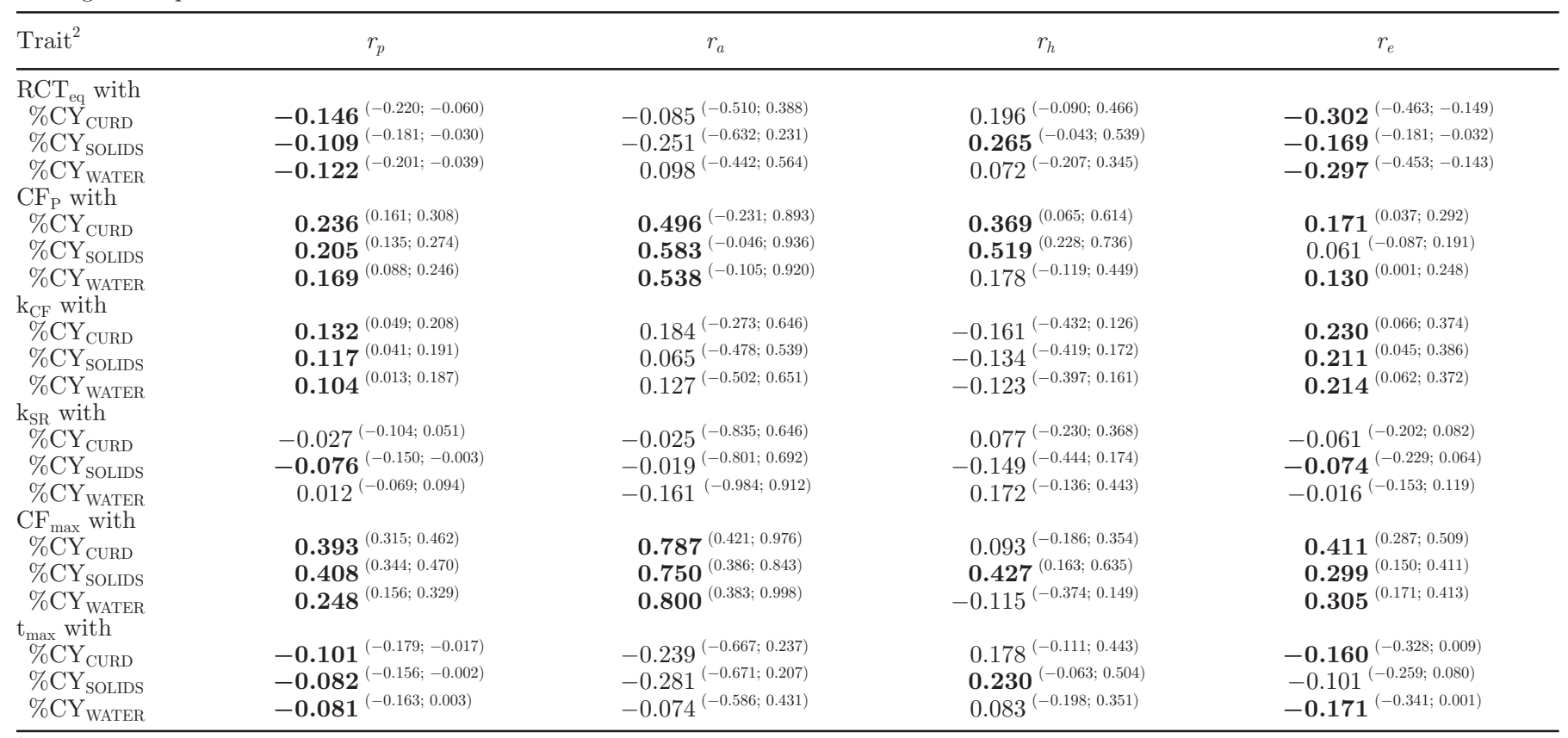

${ }^{1}$ Estimates are the median of the marginal posterior density of the parameter (lower and upper bounds of the $95 \%$ highest posterior density region in parentheses); bold indicates correlations with $\geq 90 \%$ of posterior probability accumulated above 0 (positive estimates) or below 0 (negative estimates).

${ }^{2} \% \mathrm{CY}_{\mathrm{CURD}}=$ weight of fresh curd as percentage of weight of milk processed; $\% \mathrm{CY}_{\text {SOLIDS }}=$ weight of curd solids as percentage of weight of milk processed; $\% \mathrm{CY}_{\text {WATER }}=$ weight of water curd as percentage of weight of milk processed; $\mathrm{RCT}_{\mathrm{eq}}=$ rennet coagulation time estimated using the equation; $\mathrm{CF}_{\mathrm{P}}=$ asymptotic potential curd firmness; $\mathrm{k}_{\mathrm{CF}}=$ curd firming instant rate constant; $\mathrm{k}_{\mathrm{SR}}=$ syneresis instant rate constant; $\mathrm{CF}_{\mathrm{max}}=$ maximum curd firmness achieved within $45 \mathrm{~min} ; \mathrm{t}_{\max }=$ time at achievement of $\mathrm{CF}_{\max }$. 
Table 4. Features of the marginal posterior density of phenotypic $\left(r_{p}\right)$, additive genetic $\left(r_{a}\right)$, herd/date $\left(r_{h}\right)$, and residual $\left(r_{e}\right)$ correlations between milk components recovery (protein, fat, solids, and energy of the curd as percentage of the protein, fat, solids, and energy of the milk processed) and traditional milk coagulation properties ${ }^{1}$

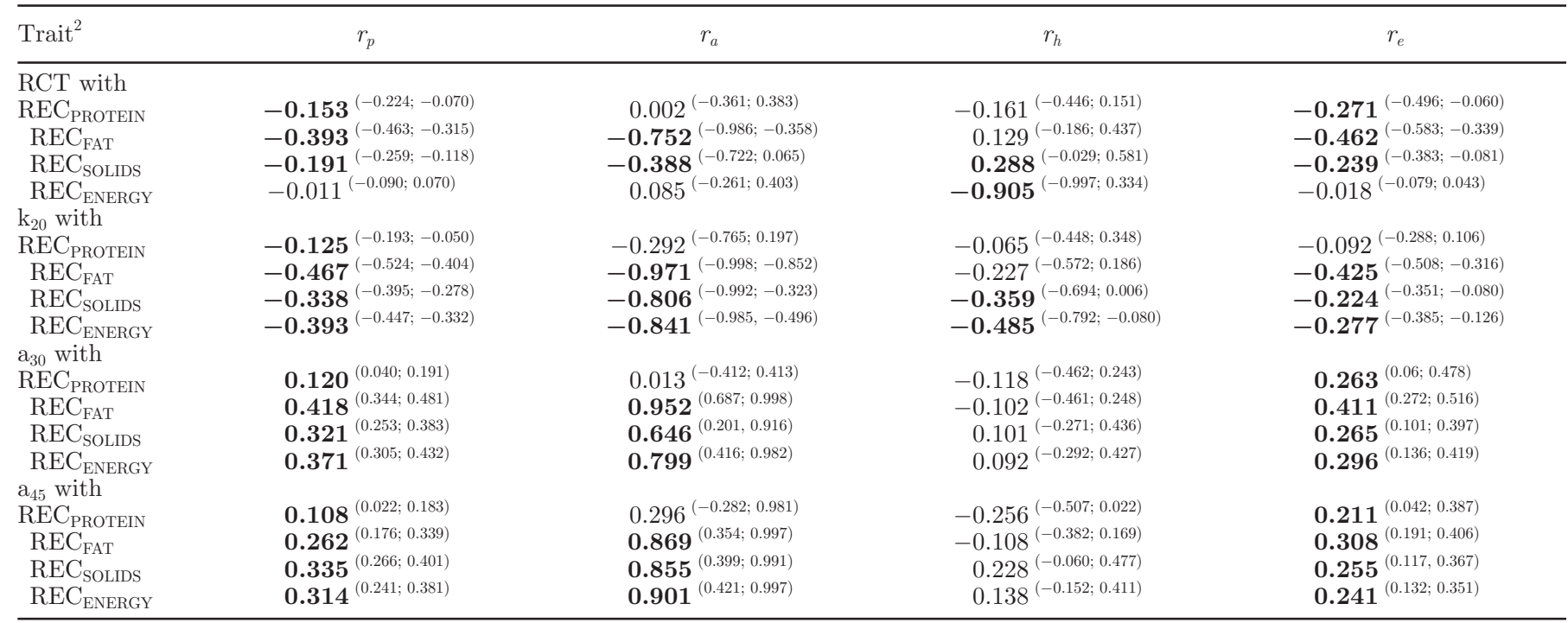

${ }^{1}$ Median of the marginal posterior density of the parameter (lower and upper bounds of the $95 \%$ highest posterior density region in parentheses); bold indicates correlations with $\geq 90 \%$ of posterior probability accumulated above 0 (positive estimates) or below 0 (negative estimates).

${ }^{2} \mathrm{REC}_{\text {PROTEIN }}=$ protein of the curd as percentage of the protein of the milk processed; $\mathrm{REC}_{\mathrm{FAT}}=$ fat of the curd as percentage of the fat of the milk processed; $\mathrm{REC}_{\mathrm{SOLIDS}}=$ solids of the curd as percentage of the solids of the milk processed; $\mathrm{REC}_{\mathrm{ENERGY}}=$ energy of the curd as percentage of energy of the milk processed; $\mathrm{RCT}=$ rennet coagulation time of samples coagulating within 45 min from enzyme addition; $\mathrm{k}_{20}=$ curd-firming time of samples reaching $20 \mathrm{~mm}$ of firmness within $45 \mathrm{~min}$ from enzyme addition; $\mathrm{a}_{30}=$ curd firmness at 30 min after enzyme addition; $\mathrm{a}_{45}=$ curd firmness at 45 min after enzyme addition.

whereas $\mathrm{t}_{\max }$ showed a much smaller (negative) correlation with CY.

\section{Relationships Between Traditional MCP, $\mathrm{CF}_{t}$, and MCF Traits Versus REC Traits}

Tables 4 and 5 show the phenotypic, genetic, herd/ date, and residual correlations between the REC traits, the traditional $\mathrm{MCP}$, the $\mathrm{CF}_{\mathrm{t}}$ parameters, and $\mathrm{MCF}$ traits. The additive genetic correlations were often greater than those observed for $\mathrm{CY}$, and tended to be similar for $\mathrm{REC}_{\mathrm{FAT}}, \mathrm{REC}_{\mathrm{SOLIDS}}$, and $\mathrm{REC}_{\text {ENERGY }}$, but different for $\mathrm{REC}_{\text {PROTEIN }}$. The traditional MCP showed strong favorable correlations with all of the REC (negative for RCT and $\mathrm{k}_{20}$ and positive for $\mathrm{a}_{30}$ and $\mathrm{a}_{45}$ ) except for $\mathrm{REC}_{\text {Protein }}$. For the individual equation parameters for $\mathrm{CF}_{\mathrm{t}}, \mathrm{RCT}_{\mathrm{eq}}$ was similar to $\mathrm{RCT}$ and $\mathrm{k}_{\mathrm{CF}}$ was similar to $\mathrm{a}_{30}, \mathrm{CF}_{\mathrm{P}}$ was positively correlated with all of the REC but presented a large variability of estimate, and $\mathrm{k}_{\mathrm{SR}}$ showed a tendency for positive correlation with only $\mathrm{REC}_{\text {PRoteIN }}$. Moreover, $\mathrm{CF}_{\max }$ showed high positive correlations with all of the REC and $t_{\max }$ showed negative correlations with all of the REC except for $\mathrm{REC}_{\text {PROTEIN }}$.

The herd/date-level correlations with the REC were, on average, much smaller than the corresponding genetic correlations. Among the traditional MCP, the only appreciable correlations were found between
RCT and $\mathrm{REC}_{\text {SOLIDS }}$ and between $\mathrm{k}_{20}$ and $\mathrm{REC}_{\text {SOLIDS }}$ and $\mathrm{REC}_{\text {ENERGY }}$. Notably, REC $\mathrm{C}_{\text {Protein }}$ seemed to be correlated negatively with $\mathrm{CF}_{\mathrm{P}}, \mathrm{CF}_{\max }$, and $\mathrm{t}_{\max }$ and positively with $\mathrm{k}_{\mathrm{SR}}$, whereas $\mathrm{REC}_{\mathrm{SOLIDS}}$ was positively correlated with $\mathrm{CF}_{\mathrm{P}}$.

The residual correlations were more homogeneous among the REC (with the exception of the almost null correlations of $\mathrm{k}_{20}, \mathrm{k}_{\mathrm{CF}}$ and $\mathrm{t}_{\max }$ with $\mathrm{REC}_{\text {PROTEIN }}$ ); they had favorable signs and ranged in absolute value from 0.124 to 0.462 . Only $\mathrm{CF}_{\mathrm{P}}$ and $\mathrm{k}_{\mathrm{SR}}$ presented very low correlations with all the REC. As seen for the CY, the phenotypic correlations of the REC were identical in sign and similar in value to the corresponding residual correlations.

\section{DISCUSSION}

\section{CY and Components}

Cheese yield (\% $\mathrm{CY}_{\text {CURD }}$ ) depends on the TS content of the milk, its recovery in curd or loss in whey and the retention of water in cheese (Figure 2). In contrast, the amount of solids retained in the curd depends largely on the fat and casein contents of the milk, because lactose, minerals, and noncasein nitrogenous compounds are retained at very low levels. The relationships between $\% \mathrm{CY}_{\mathrm{CURD}}$ and the fat and protein (casein) contents of 
milk are well known. However, those between CY and the REC traits have not been extensively studied. The complex relationships among these cheesemaking traits were previously reported (Bittante et al., 2013a) and are summarized in Figure 3. Although all of the correlations are positive, their importance clearly differs when one considers them at the phenotypic, additive genetic, herd/date, and residual levels.

When the study of correlations is extended to other traits, the resulting picture becomes even more complicated. In particular, the correlations between CY and the milk coagulation, curd firming, and syneresis traits are highly affected by milk composition; this is because the protein (casein) and fat contents, which are the major contributors to $\% \mathrm{CY}_{\text {SOLIDS, }}$, also affect the coagulation properties. To improve our understanding of causative relationships, therefore, it would seem more useful to analyze the REC, which are not directly affected by the nutrient concentration of the milk.

\section{Protein Recovery in Cheese and Loss in Whey}

The $\mathrm{REC}_{\text {Protein }}$, which quantifies the complex phenomena through which proteins are transferred from milk to cheese (Emmons et al., 2003), is phenotypically related to all of the other considered cheesemaking traits (Figure 3; Bittante et al., 2013a). The existing literature offers very little information on this topic. Curd firmness obtained using the same milk lot was found to increase when the interval between rennet addition and curd cutting was prolonged (Bynum and Olson, 1982; Riddell-Lawrence and Hicks, 1989; Johnson et al., 2001), perhaps reflecting minor changes in the whey losses of nitrogen compounds. In an analysis of the results obtained when the same herd was used for monthly cheesemaking sessions, Ng-Kwai-Hang et al. (1989) obtained positive correlations between protein whey losses expressed as a ratio with respect to the milk protein content and all of the traditional MCP

Table 5. Features of the marginal posterior density of phenotypic $\left(r_{p}\right)$, additive genetic $\left(r_{a}\right)$, herd/date $\left(r_{h}\right)$, and residual $\left(r_{e}\right)$ correlations between milk components recovery (protein, fat, solids, and energy of the curd as percentage of the protein, fat, solids, and energy of the milk processed) and curd firming model parameters and derived maximum curd-firmness traits ${ }^{1}$

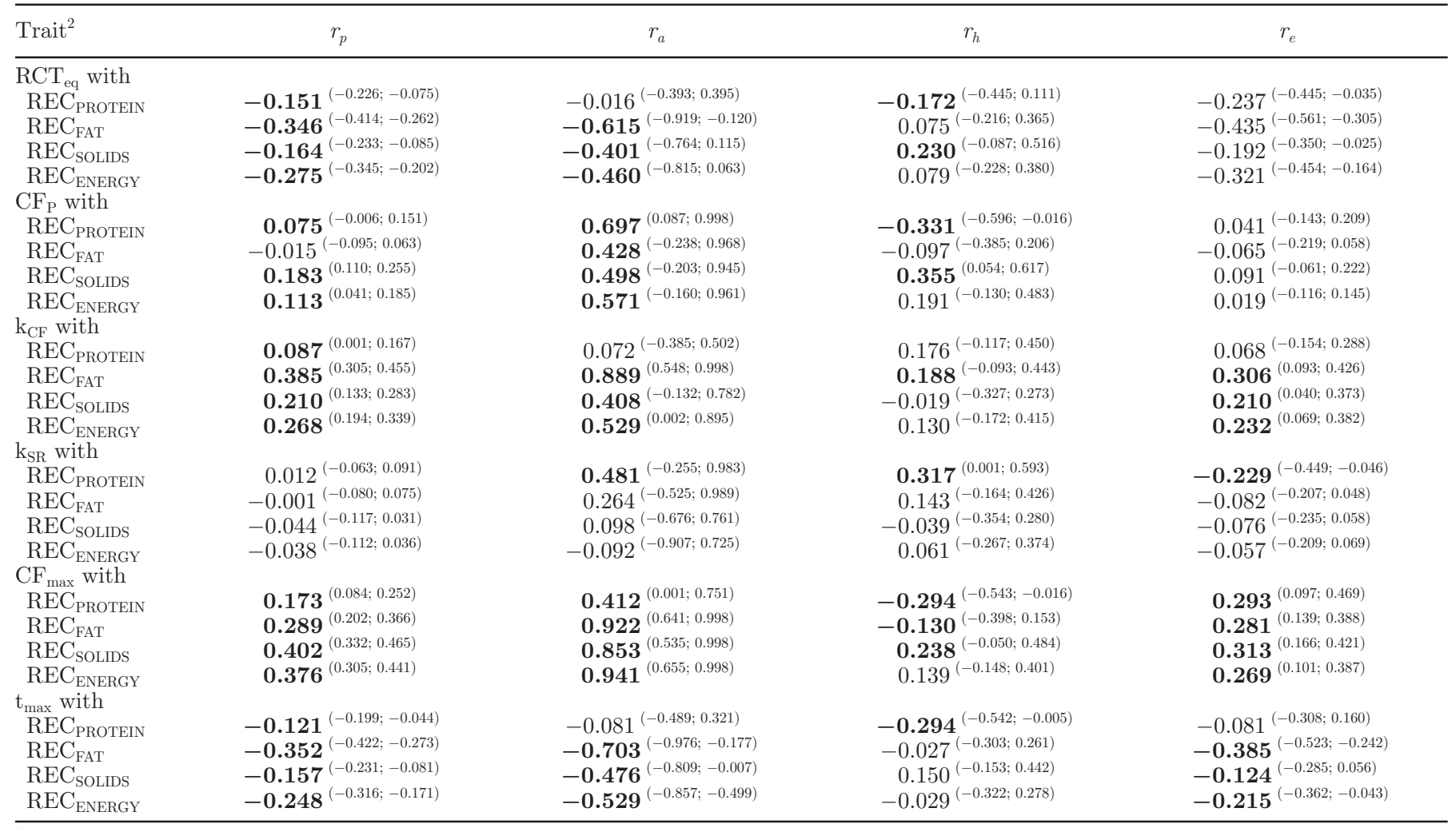

${ }^{1}$ Median of the marginal posterior density of the parameter (lower and upper bounds of the $95 \%$ highest posterior density region in parentheses); bold indicates correlations with $\geq 90 \%$ of posterior probability accumulated above 0 (positive estimates) or below 0 (negative estimates).

${ }^{2} \mathrm{REC}_{\text {PROTEIN }}=$ protein of the curd as percentage of the protein of the milk processed; $\mathrm{REC}_{\mathrm{FAT}}=$ fat of the curd as percentage of the fat of the milk processed; $\mathrm{REC}_{\mathrm{SOLIDS}}=$ solids of the curd as percentage of the solids of the milk processed; $\mathrm{REC}_{\mathrm{ENERGY}}=$ energy of the curd as percentage of energy of the milk processed; $\mathrm{RCT}_{\mathrm{eq}}=$ rennet coagulation time estimated using the equation; $\mathrm{CF}_{\mathrm{P}}=$ asymptotic potential curd firmness; $\mathrm{k}_{\mathrm{CF}}$ $=$ curd firming instant rate constant; $\mathrm{k}_{\mathrm{SR}}=$ syneresis instant rate constant; $\mathrm{CF}_{\max }=$ maximum curd firmness achieved within 45 min; $\mathrm{t}_{\max }=$ time at achievement of $\mathrm{CF}_{\max }$. 
Phenotypic correlations

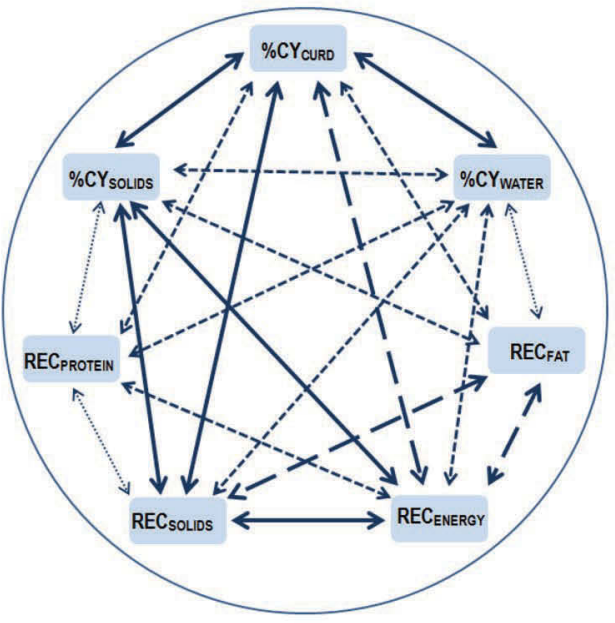

Herd/date correlations

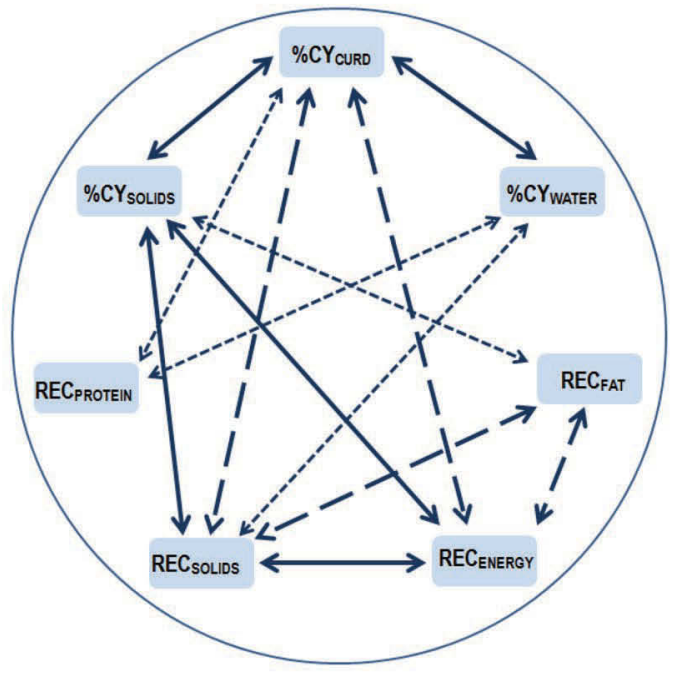

Additive genetic correlations

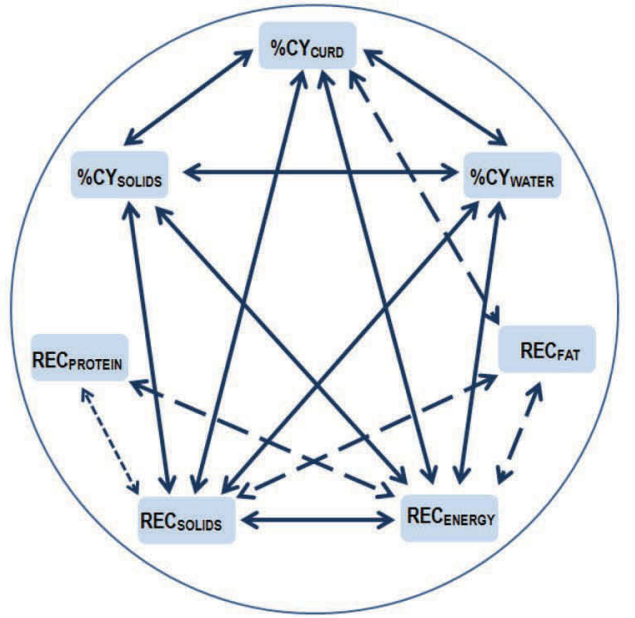

Residual correlations

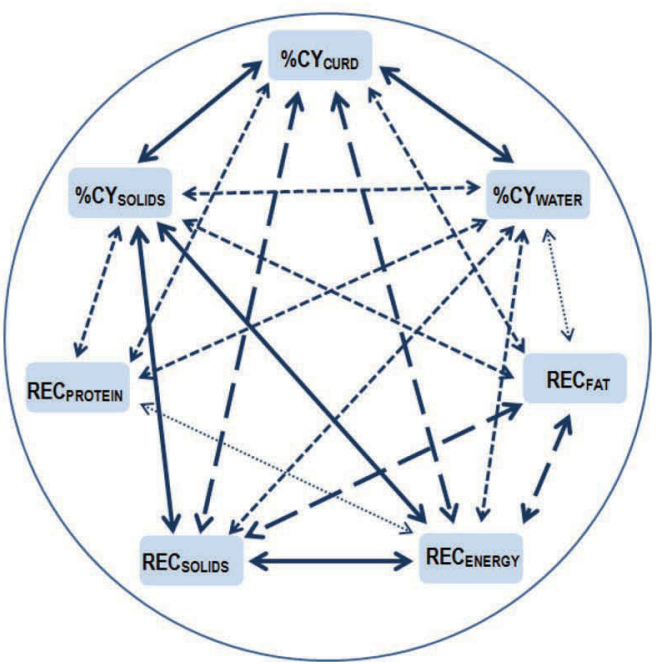

Figure 3. Phenotypic, additive genetic, herd/date, and residual correlations between cheese yield and curd recovery traits $($ solid line $=>0.75$; long dashed line $=>0.50$; short dashed line $=>0.25$; dotted line $=<0.25$ ). $\mathrm{REC}_{\text {PRoteIN }}=$ protein of the curd as percentage of the protein of the milk processed; $\mathrm{REC}_{\mathrm{FAT}}=$ fat of the curd as percentage of the fat of the milk processed; $\mathrm{REC}_{\mathrm{SOLIDS}}=$ solids of the curd as percentage of the solids of the milk processed; $\mathrm{REC}_{\mathrm{ENERGY}}=$ energy of the curd as percentage of energy of the milk processed; $\% \mathrm{CY} \mathrm{CURD}_{\mathrm{C}}=$ weight of fresh curd as percentage of weight of milk processed; $\% \mathrm{CY}_{\text {SOLIDS }}=$ weight of curd solids as percentage of weight of milk processed; $\% \mathrm{CY}$ WATER $=$ weight of water curd as percentage of weight of milk processed. Color version available online.

[0.29 (unfavorable), 0.22 (unfavorable), and 0.24 (favorable) for RCT, $\mathrm{k}_{20}$, and $\mathrm{a}_{30}$, respectively].

Other studies compared milk from cows of different breeds characterized by very different MCP or used the same breed but used the average MCP to separate the milk by cow or farm. Malacarne et al. (2006) compared Holstein Friesian and Brown Swiss cows on 26 Parmigiano-Reggiano cheesemakings, and found nonsignificant differences in $100-\mathrm{REC}_{\text {PROTEIN }}$. Ikonen et al. (1999) compared milk with RCT > 30 min (the so called noncoagulating samples) with good-MCP milk for the production of Emmental cheese, and found, on 4 cheeses, not significantly different $\mathrm{REC}_{\text {PRoteIN }}$ in the
2 cases. Bonfatti et al. (2014) tested 20 model cheeses and found that $\mathrm{REC}_{\text {PROTEIN }}$ tended to increase with MCP (though not to a significant degree), even though the average $\mathrm{REC}_{\text {PROTEIN }}$ was found to be unusually low (54-57\%).

As genetic variants of milk proteins can strongly affect MCP (Bittante et al., 2012), some studies have analyzed the effects of such variants on the cheesemaking ability of milk. In general, these studies found that the presence of the $k-\mathrm{CN} B$ variant had a positive effect on REC Protein (Wedholm et al., 2006; Alipanah and Kalashnikova, 2007). Bonfatti et al. (2011) further showed that the differences between milk with different 
proportions of $\mathrm{A}$ and $\mathrm{B} \kappa-\mathrm{CN}$ were explained by their effects on the proportion of $\kappa-\mathrm{CN}$ in the total casein.

The existing literature does not include any information regarding the genetic, herd, and residual correlations between MCP and $\mathrm{REC}_{\mathrm{PROTEIN}}$. The most important phenotypic, additive genetic, herd/date, and residual correlations between $\mathrm{MCP}$ and $\mathrm{CF}_{\mathrm{t}}$ traits as well as CY and REC traits obtained in the present study are summarized in Figure 4.

From the genetic point of view, $\mathrm{REC}_{\text {Protein }}$ was not found to be directly correlated with the CY; instead, it was directly correlated with $\mathrm{REC}_{\text {SOLIDS }}$ and $\mathrm{RE}$ $\mathrm{C}_{\text {ENERGY }}$, which are strongly related to the CY traits (Figure 3; Bittante et al., 2013a). Although we found that $\mathrm{REC}_{\text {PROTEIN }}$ was the most heritable of the studied traits (Table 1), its genetic correlations with the traditional MCP were very low, explaining the relative lack of relationships at the phenotypic level (summarized in Figure 4). The modeled $\mathrm{CF}_{\mathrm{t}}$ pattern differed from that of the traditional $\mathrm{MCP}$, reflecting the strong additive genetic association observed between $\mathrm{REC}_{\text {Protern }}$ and $\mathrm{CF}_{\mathrm{P}}$ or $\mathrm{CF}_{\max }$ (Figure 4). Thus, this modeling is better able to collect the available information during the processes of milk coagulation, curd firming, and syneresis, and thereafter condense it into a few easily interpretable parameters (Bittante et al., 2015). In particular, it seems clear that $\mathrm{REC}_{\text {PROTEIN }}$ is genetically linked to a high $\mathrm{CF}$ in the last phase of the lactodynamographic test, but not to the coagulation time or the initial velocity of curd firming.

With respect to the herd/date correlations, the herd explains only small proportions of the total variances of the MCP (Ikonen et al., 1997; Tyrisevä et al., 2003) and $\mathrm{CF}_{\mathrm{t}}$ (Table 1), whereas it is more important for the REC (Bittante et al., 2013a). As seen for the additive genetic correlations, the traditional MCP presented low herd/date-effect correlations with $\mathrm{REC}_{\text {PROTEIN }}$, whereas the latter was much more correlated (though unfavorably) with $\mathrm{CF}_{\mathrm{P}}$ and somewhat correlated (favorably) with $\mathrm{k}_{\mathrm{SR}}$ (Figure 4). The practical relevance of these results should be studied in the future. We found that the residual correlations, which had not previously been reported in the literature, were similar to the phenotypic correlations (Figure 4).

\section{Fat Recovery in Cheese and Loss in Whey}

Experiments using the same milk lot and prolonging the vat rest time before curd cutting yielded contradictory results regarding the effect of $\mathrm{CF}$ on $\mathrm{REC}_{\mathrm{FAT}}$ (Bynum and Olson, 1982; Riddell-Lawrence and Hicks, 1989; Johnson et al., 2001). The favorable phenotypic correlations observed in the present study between all of the traditional $\mathrm{MCP}$ and $\mathrm{REC}_{\mathrm{FAT}}$, summarized in
Figure 4, fully confirm the results obtained by $\mathrm{Ng}$ Kwai-Hang et al. (1989) in individual model cheeses and Ikonen et al. (1999) in Emmental cheese, but not those obtained by Bonfatti et al. (2014) in model cheeses with very low $\mathrm{REC}_{\mathrm{FAT}}(60.2-63.9 \%)$.

No comparable data are available in the literature, but the favorable phenotypic correlations found herein between $\mathrm{REC}_{\mathrm{FAT}}$ and the $\mathrm{CF}_{\mathrm{t}}$ parameters (excluding $\mathrm{CF}_{\mathrm{P}}, \mathrm{k}_{\mathrm{SR}}$, and $\left.\mathrm{CF}_{\max }\right)$ confirm the results observed for all of the traditional MCP (Figure 4).

With respect to the genetic correlations, the existing literature lacks data for the $\mathrm{MCP}$, the $\mathrm{CF}_{\mathrm{t}}$ equation parameters, and their derived traits. The $\mathrm{REC}_{\mathrm{FAT}}$, which has the lowest heritability of the studied cheesemaking traits (Table 1 ), is correlated with $\mathrm{REC}_{\text {SoLIDS, }}$ $\mathrm{REC}_{\text {ENERGY, }}$ and $\% \mathrm{CY}_{\mathrm{CURD}}$ (Bittante et al., 2013a). Unlike $\mathrm{REC}_{\text {PROTEIN }}$, however, it shows very high and favorable genetic correlations with all of the considered coagulation, curd firming, and syneresis traits (with the exceptions of $\mathrm{CF}_{\mathrm{P}}$ and $\mathrm{k}_{\mathrm{SR}}$, which produced only small correlations), as summarized in Figure 4. Thus, both the traditional measures and the new coagulation and $\mathrm{CF}$ traits may be used for the indirect selection of $\mathrm{REC}_{\mathrm{FAT}}$ and $\% \mathrm{CY}_{\mathrm{CURD}}$ (through $\mathrm{REC}_{\mathrm{FAT}}$ ) independent from the milk solid content. This is further confirmed by our observation that the additive genetic correlations between the MCP and $\mathrm{CF}_{\mathrm{t}}$ traits on one side and $\mathrm{REC}_{\text {SOLIDS }}$ and $\mathrm{REC}_{\text {ENERGY }}$ on the other side are more similar to those with $\mathrm{REC}_{\mathrm{FAT}}$ than with $\mathrm{REC}_{\mathrm{PROTEIN}}$.

The herd/date correlations between coagulation and $\mathrm{REC}_{\mathrm{FAT}}$ were all very low, whereas $\mathrm{REC}_{\text {SOLIDS }}$ and $\mathrm{REC}_{\text {ENERGY }}$ presented some favorable herd/date correlations with $\mathrm{k}_{20}$ and $\mathrm{CF}_{\mathrm{P}}$. These results suggest that, at the farm level, these recovery traits cannot be efficiently predicted from the coagulation, curd firming, or syneresis patterns. Again, the residual correlations were similar to the corresponding phenotypic correlations.

\section{Retention of Water in Cheese and CY}

Similar to the measures of fat and protein, the retention of water in cheese is important to $\% \mathrm{CY}_{\mathrm{CURD}}$. Although water retention could be considered positively because it increases $\% \mathrm{CY}_{\mathrm{CURD}}$, the final moisture content of cheese is often fixed and excess water is eliminated (Janhøj and Qvist, 2010). Indeed, incomplete draining of the curd can alter cheeses during ripening, leading to defects in and depreciation of the final product (Martin et al., 1997). The \%CY WATER and $\% \mathrm{CY}_{\text {SOLIDS }}$ traits are strongly correlated with each other (Figure 3; Bittante et al., 2013a) only from the genetic point of view, although both of them exhibit strong phenotypic, genetic, herd/date, and residual correlations with $\% \mathrm{CY}_{\mathrm{CURD}}$. Moreover, $\% \mathrm{CY}_{\text {WATER }}$ and 
$\% \mathrm{CY}_{\text {SOLIDS }}$ show similar additive genetic correlations with the MCP and $\mathrm{CF}_{\mathrm{t}}$ traits, but different phenotypic, herd/date (particularly for $\% \mathrm{CY}_{\text {SOLIDS }}$ ), and residual (particularly for $\% \mathrm{CY}_{\text {WATER }}$ ) correlations with traits depicting the late curd-firming process (Figure 4). This correlation structure confirms that the retention of water is strictly linked to the retention of solids, and that $\% \mathrm{CY}_{\text {WATER }}$ likely should not be used in strategies aimed at modifying the ratio between moisture and solids in cheese. Instead, a different trait that relates moisture to fat and protein should be applied.

The direct and indirect effects of milk composition (especially the quantity or quality of fat and protein) make it difficult to analyze the direct relationships between $\% \mathrm{CY}_{\mathrm{CURD}}$ and coagulation, as well as between the curd firming and syneresis traits, perhaps explain-

\section{Phenotypic correlations}

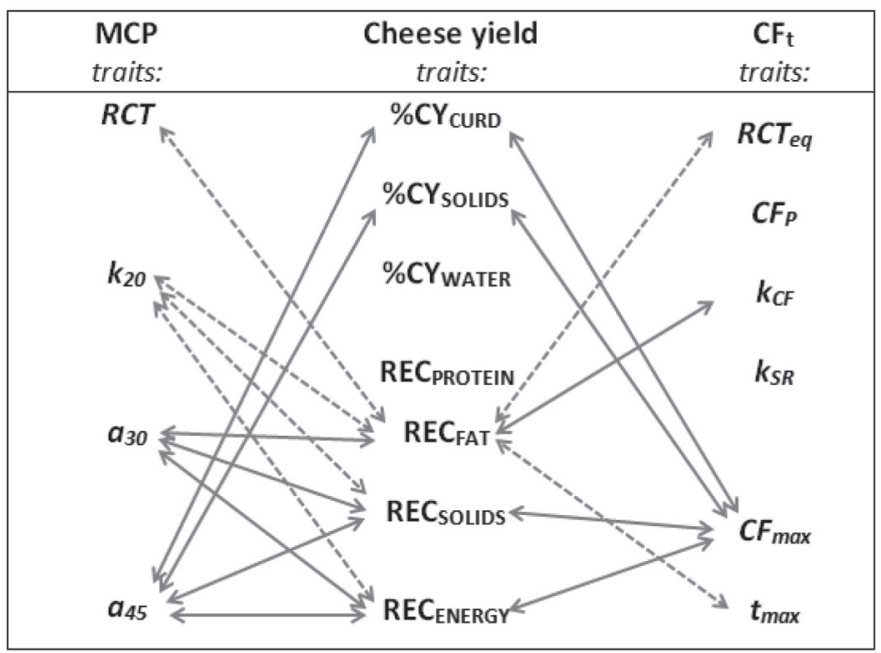

\section{Herd correlations}

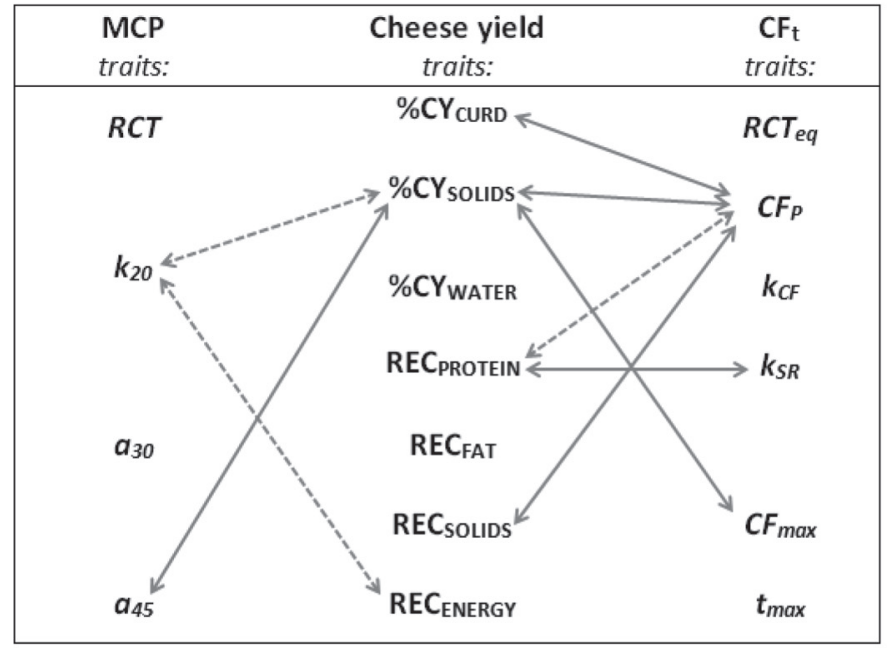

\section{Additive genetic correlations}

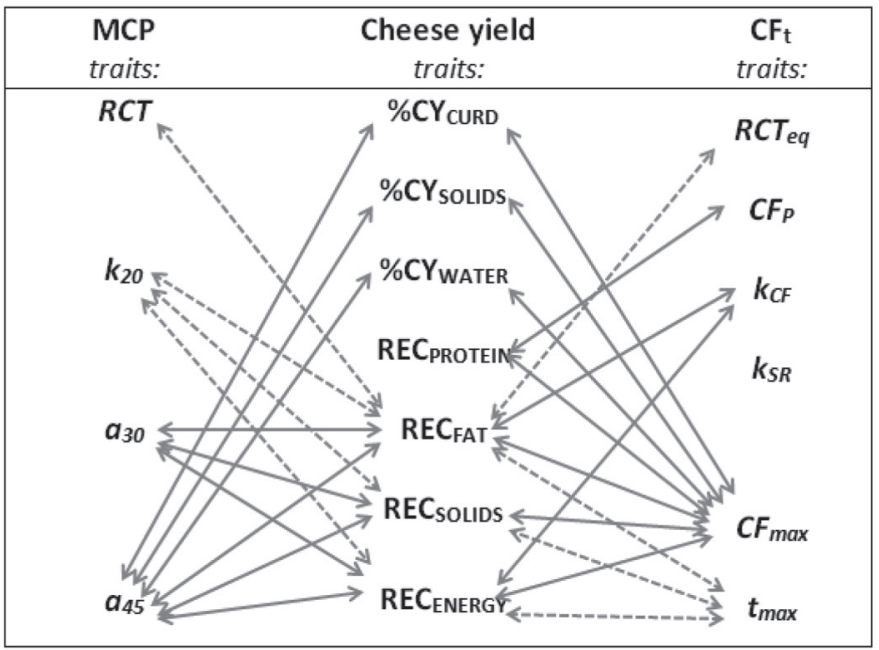

\section{Residual correlations}

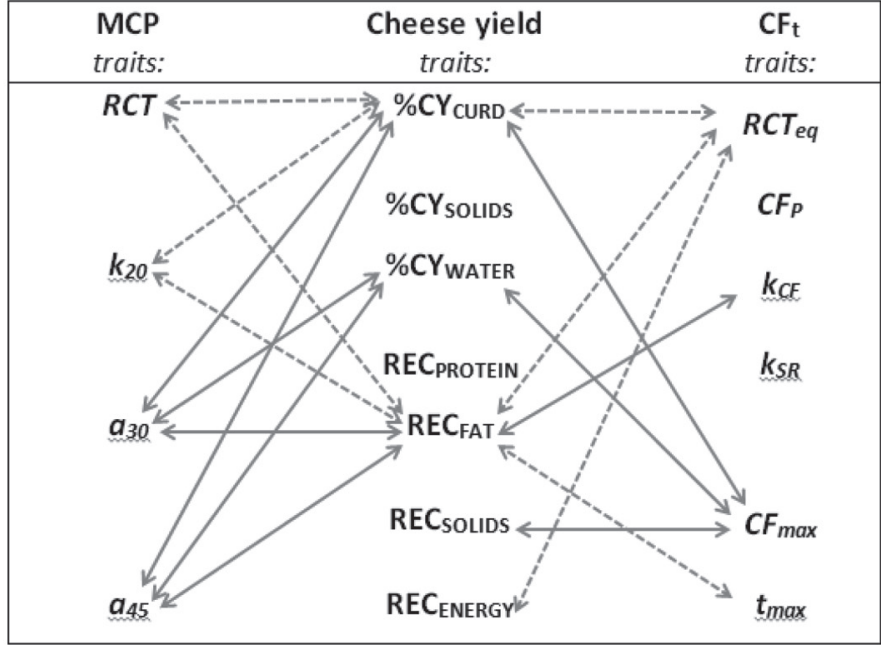

Figure 4. Summary of the relevant (estimates greater than 0.30 or lower than -0.30 ) and reliable (with the $95 \%$ highest posterior density region does not include 0) correlations between cheese yield traits, traditional single-point milk coagulation properties (MCP) and curd firming modeling parameters $\left(\mathrm{CFt}\right.$ ), and derived traits ( solid lines $=$ positive correlations, dashed lines $=$ negative correlations). $\mathrm{REC}_{\mathrm{PROTEIN}}=$ protein of the curd as percentage of the protein of the milk processed; $\mathrm{REC}_{\mathrm{FAT}}=$ fat of the curd as percentage of the fat of the milk processed; $\mathrm{REC}_{\mathrm{SOLIDS}}=$ solids of the curd as percentage of the solids of the milk processed; REC $\mathrm{ENERGY}_{\mathrm{F}}=$ energy of the curd as percentage of energy of the milk processed; $\% \mathrm{CY}_{\mathrm{CURD}}=$ weight of fresh curd as percentage of weight of milk processed; $\%$ CY $\mathrm{SoLIDS}=$ weight of curd solids as percentage of weight of milk processed; $\% \mathrm{CY}_{\text {WATER }}=$ weight of water curd as percentage of weight of milk processed; RCT $=$ rennet coagulation time; $\mathrm{k}_{20}=$ curd-firming time of samples reaching $20 \mathrm{~mm}$ of firmness within $45 \mathrm{~min}$ from enzyme addition; a $30=$ curd firmness at $30 \mathrm{~min}$ after enzyme addition; $\mathrm{CFP}=$ potential asymptotical $\mathrm{CF}$ in absence of syneresis; $\mathrm{k}_{\mathrm{CF}}=$ curd firming instant rate constant; $\mathrm{k}_{\mathrm{SR}}=\mathrm{syneresis}$ instant rate constant and representation of maximum $\mathrm{CF}$ traits $(\mathrm{MCF}): \mathrm{CF}_{\max }=\operatorname{maximum} \mathrm{CF}_{\mathrm{t}}$ value; $\mathrm{t}_{\max }=$ time at $\mathrm{CF}_{\max }$. 
ing the contradictory results of such studies in the literature (Pretto et al., 2013; Bonfatti et al., 2014). Both $\mathrm{REC}_{\mathrm{FAT}}$ and $\mathrm{REC}_{\text {PROTEIN }}$ combined with the milk fat and protein contents may be a more useful set of traits for understanding the effects of herd/date, genetic, and residual factors on CY phenotypes. To increase the efficiency of dairy populations whose produced milk is primarily employed in cheesemaking, both $\mathrm{REC}_{\mathrm{FAT}}$ and $\mathrm{REC}_{\text {PRoteIN }}$ should be considered for inclusion among the breeding goals.

Direct selection for CY and REC might be the most effective selection strategy, but population-wide recording of individual phenotypes for those traits is not applicable because of limitations imposed by features of the cheese-making procedure. Although breeding values for $\mathrm{CY}$ and REC have been obtained from direct measures of phenotypes in experimental studies (Bittante et al., 2013a), selection strategies based on direct measures of CY and REC would be very hard to implement. High throughput (potentially, hundreds of samples per hour), ease of use, and reduced cost of analysis make Fourier transform infrared (FTIR) spectroscopy a promising alternative for the assessment of $\mathrm{CY}$ and REC at the population level (Cecchinato et al., 2015; Ferragina et al., 2015).

\section{CONCLUSIONS}

The use of an individual model cheesemaking strategy allowed us to collect a large quantity of information regarding $\% \mathrm{CY}_{\mathrm{CURD}}$ and its solid and moisture components as well as the recovery efficiencies of fat, protein, TS, and energy in the curd. Both $\mathrm{REC}_{\text {PROTEIN }}$ and $\mathrm{REC}_{\mathrm{FAT}}$ were found to be particularly powerful instruments for understanding the relationships between milk technological properties and cheese quantity or quality. Our results indicate that, in addition to its potential usefulness at the industry level, $\mathrm{REC}_{\text {PRotein }}$ (for which FTIR calibration equations are already available) should be considered for inclusion in breeding goals aimed at improving the efficiency of cheesemaking at the population level. Indeed, this trait exhibited large exploitable genetic variation and weak additive genetic correlations with milk composition and $\mathrm{MCP}$. The $\mathrm{REC}_{\mathrm{FAT}}$ (a moderately heritable trait) could be improved through the $\mathrm{CF}_{\mathrm{t}}$ traits, especially those recorded during the late phase of curd firming. Finally, our results demonstrated that the traditional MCP have limited relevance, especially the RCT, for predicting individual cheese yield. Therefore, their use for this purpose in the dairy industry and breeding programs seems questionable.

\section{ACKNOWLEDGMENTS}

The authors thank the Autonomous Province of Trento (Italy) for funding the project, the project "Strengthening of the facilities supporting biotechnology research" of the Veneto Region (Italy) ("RISIB" SMUPR project 4145: Regional competitiveness and job creation; FESR 2007/2013 Action 1.1.1) for the availability of the instruments of the NIRS Food laboratory; the Superbrown Consortium; the Superbrown Consortium of Bolzano and Trento (Trento, Italy) for their support in sampling and recording activities; the Italian Brown Swiss Cattle Breeders (ANARB, Verona, Italy) for providing pedigree information; and Claudio Cipolat-Gotet, Mauro Penasa, Massimo De Marchi, Nicola Cologna, and Ilario Bazzoli (Department of Agronomy, Food, Natural Resources, Animals and Environment (DAFNAE), University of Padova, Legnaro, Italy) for their cooperation in collecting samples and setting up the model cheese procedure.

\section{REFERENCES}

Alipanah, M., and L. A. Kalashnikova. 2007. Influence of K-casein genetic variant on cheese making ability. J. Anim. Vet. Adv. 6:855857.

Annibaldi, S., F. Ferri, and R. Morra. 1977. Nuovi orientamenti nella valutazione tecnica del latte: Tipizzazione lattodinamografica. Sci. Tecn. Latt. Cas. 28:115-126.

Bittante, G. 2011. Modeling rennet coagulation time and curd firmness of milk. J. Dairy Sci. 94:5821-5832.

Bittante, G., C. Cipolat-Gotet, and A. Cecchinato. 2013a. Genetic parameters of different measures of cheese yield and milk nutrient recovery from an individual model cheese-manufacturing process. J. Dairy Sci. 96:7966-7979.

Bittante, G., C. Cipolat-Gotet, F. Malchiodi, E. Sturaro, F. Tagliapietra, S. Schiavon, and A. Cecchinato. 2015. Effect of dairy farming system, herd, season, parity and days in milk on modeling of the coagulation, curd firming, and syneresis of bovine milk. J. Dairy Sci. 98:2759-2774.

Bittante, G., B. Contiero, and A. Cecchinato. 2013b. Prolonged observation and modelling of milk coagulation, curd firming, and syneresis. Int. Dairy J. 29:115-123.

Bittante, G., M. Penasa, and A. Cecchinato. 2012. Invited review: Genetics and modeling of milk coagulation properties. J. Dairy Sci. 95:6843-6870.

Bonfatti, V., A. Cecchinato, G. Di Martino, M. De Marchi, L. Gallo, and P. Carnier. 2011. Effect of $\kappa$-casein B relative content in bulk milk $\kappa$-casein on Montasio, Asiago, and Caciotta cheese yield using milk of similar protein composition. J. Dairy Sci. 94:602-613.

Bonfatti, V., M. Tuzzato, G. Chiarot, and P. Carnier. 2014. Variation in milk coagulation properties does not affect cheese yield and composition of model cheese. Int. Dairy J. In press.

Bynum, D. G., and N. F. Olson. 1982. Influence of curd firmness at cutting on Cheddar cheese yield and recovery of milk constituents. J. Dairy Sci. 65:2281-2290.

Cecchinato, A., A. Albera, C. Cipolat-Gotet, A. Ferragina, and G. Bittante. 2015. Genetic parameters of cheese yield and curd nutrient recovery or whey loss traits predicted using Fourier-transform infrared spectroscopy of samples collected during milk recording on Holstein, Brown Swiss and Simmental dairy cows. J. Dairy Sci. 98:4914-4927. 
Cecchinato, A., C. Cipolat-Gotet, J. Casellas, M. Penasa, A. Rossoni, and G. Bittante. 2013. Genetic analysis of rennet coagulation time, curd-firming rate, and curd firmness assessed on an extended testing period using mechanical and near-infrared instruments. J. Dairy Sci. 96:50-62.

Cipolat-Gotet, C., A. Cecchinato, M. De Marchi, and G. Bittante. 2013. Factors affecting variation of different measures of cheese yield and milk nutrients recovery from an individual model cheesemanufacturing process. J. Dairy Sci. 96:7952-7965.

Cipolat-Gotet, C., A. Cecchinato, M. De Marchi, M. Penasa, and G. Bittante. 2012. Comparison between mechanical and near-infrared optical methods for assessing coagulation properties of bovine milk. J. Dairy Sci. 95:6806-6819.

Emmons, D. B. 1993. Economic importance of cheese yield. Pages 10-11 in International Dairy Federation Special Issue 9301, Factors Affecting the Yield of Cheese. International Dairy Fed., Brussels, Belgium.

Emmons, D. B., C. Dubé, and H. W. Modler. 2003. Transfer of protein from milk to cheese. J. Dairy Sci. 86:469-485.

Ferragina, A., G. de los Campos, A. Vazquez, A. Cecchinato, and G. Bittante. 2015. Bayesian regression models outperform partial least squares methods for prediction of milk components and technological properties using infrared spectra data. J. Dairy Sci. 98:8133-8151.

Gelfand, A., and A. F. M. Smith. 1990. Sampling based approaches to calculating marginal densities. J. Am. Stat. Assoc. 85:398-409.

Gelman, A., and D. B. Rubin. 1992. Inference from iterative simulation using multiple sequences. Stat. Sci. 7:457-511.

Geweke, J. 1992. Evaluating the accuracy of sampling-based approaches to the calculation of posterior moments (with discussion). Pages 164-193 in Bayesian Statistics. J. O. Berger, J. M. Bernardo, A. P Dawid, and A. F. M. Smith, ed. Oxford University Press, Oxford, UK.

Geyer, C. J. 1992. Practical Markov chain Monte Carlo. Stat. Sci. $7: 473-483$.

Hallén, E., A. Lundén, T. Allmere, and A. Andrén. 2010. Casein retention in curd and loss of casein into whey at chymosin-induced coagulation of milk. J. Dairy Res. 77:71-76.

Ikonen, T., M. Ojala, and E.-L. Syväoja. 1997. Effects of composite casein and $\beta$-lactoglobulin genotypes on renneting properties and composition of bovine milk by assuming an animal model. Agric. Food Sci. 6:283-294.

Ikonen, T., O. Ruottinen, E.-L. Syväoja, K. Saarinen, E. Pahkala, and M. Ojala. 1999. Effect of milk coagulation properties of herd bulk milks on yield and composition of Emmental cheese. Agric. Food Sci. 8:411-422

International Dairy Federation. 2011. The World Dairy Situation. Bulletin 451/2011. International Dairy Federation, Brussels, Belgium.

Janhøj, T., and K.B. Qvist 2010. The Formation of Cheese Curd. Pages 130-165 in Technology of Cheesemaking. B. A. Law, and A. Y. Tamine, ed. Wiley-Blackwell, Ames, IA.

Johnson, M. E., C. M. Chen, and J. J. Jaeggi. 2001. Effect of rennet coagulation time on composition, yield, and quality of reduced-fat Cheddar cheese. J. Dairy Sci. 84:1027-1033.

Kefford, B., M. P. Christian, B. J. Sutherland, J. J. Mayes, and C. Grainger. 1995. Seasonal influences on Cheddar cheese manufacture: influence of diet quality and stage of lactation. J. Dairy Res. 62:529-537.

Law, B. A., and A. Y. Tamine, eds. 2010. Technology of Cheesemaking. 2nd ed. John Wiley \& Sons, Ltd., Chicester, UK.
Malacarne, M., A. Summer, E. Fossa, P. Formaggioni, P. Franceschi, M. Pecorari, and P. Mariani. 2006. Composition, coagulation properties and Parmigiano-Reggiano cheese yield of Italian Brown and Italian Friesian herd milks. J. Dairy Res. 73:171-177.

Martin, B., J.-F. Chamba, J.-B. Coulon, and E. Perreard. 1997. Effect of chemical composition and clotting characteristics on chemical and sensory properties of Reblochon de Savoie cheese. J. Dairy Res. 64:157-162.

Martin. B., D. Pomies, P. Pradel, I. Verdier-Metz, and B. Remond. 2009. Yield and sensory properties of cheese made with milk from Holstein or Montbeliarde cows milked twice or once daily. J. Dairy Sci. 92:4730-4737.

McMahon, D. J., and R. J. Brown. 1982. Evaluation of Formagraph for comparing rennet solutions. J. Dairy Sci. 65:1639-1642.

Mistry, V. V., M. J. Brouk, K. M. Kaperson, and E. Martin. 2002. Cheddar cheese from milk of Holstein and Brown Swiss cows. Milchwissenschaft 57:19-23.

NRC. 2001 Nutrient Requirements of Dairy Cattle. 7th rev. ed. Natl. Acad. Press Washington, DC.

Ng-Kwai-Hang, K. F. I. Politis, R. I. Cue, and A. S. Marziali. 1989. Correlations between coagulation properties of milk and cheese yielding capacity and cheese composition. Can. Inst. Food Sci. Technol. J. 22:291-294.

Othmane, M. H., J. A. Carriedo, L. F. de la Fuente Crespo, and F. San Primitivo. 2002a. An individual laboratory cheese-making method for selection in dairy ewes. Small Rumin. Res. 45:67-73.

Othmane, M. H., J. A. Carriedo, F. San Primitivo, and L. F. De La Fuente. 2002b. Genetic parameters for lactation traits of milking ewes: protein content and composition, fat, somatic cells and individual laboratory cheese yield. Genet. Sel. Evol. 34:581-596.

Othmane, M. H., L. F. De La Fuente, J. A. Carriedo, and F. San Primitivo. 2002c. Heritability and genetic correlations of test day milk yield and composition, individual laboratory cheese yield, and somatic cell count for dairy ewes. J. Dairy Sci. 85:2692-2698.

Pretto, D., M. De Marchi, M. Penasa, and M. Cassandro. 2013. Effects of milk composition and coagulation traits on Grana Padano cheese yield under field conditions. J. Dairy Res. 80:1-5.

Riddell-Lawrence, S., and C. L. Hicks. 1989. Effect of curd firmness on stirred curd cheese yield. J. Dairy Sci. 72:313-321.

Sorensen, D., and D. Gianola. 2002. Likelihood, Bayesian, and MCMC Methods in Quantitative Genetics. Springer-Verlag, New York, NY

Sturaro, E., E. Marchiori, G. Cocca, M. Penasa, M. Ramanzin, and G. Bittante. 2013. Dairy systems in mountainous areas: Farm animal biodiversity, milk production and destination, and land use. Livest. Sci. 158:157-168

Summer, A., P. Franceschi, A. Bollini, P. Formaggioni, F. Tosi, and P. Mariani. 2003. Seasonal variations of milk characteristics and cheesemaking losses in the manufacture of Parmigiano-Reggiano cheese. Vet. Res. Commun. 27(Suppl. 1):663-666.

Tyrisevä, A.-M., T. Ikonen, and M. Ojala. 2003. Repeatability estimates for milk coagulation traits and non-coagulation of milk in Finnish Ayrshire cows. J. Dairy Res. 70:91-98.

Verdier-Metz, I., J. B. Coulon, and P. Pradel. 2001. Relationship between milk fat and protein contents and cheese yield. Anim. Res. 50:365-371.

Wedholm, A., L. B. Larsen, H. Lindmark-Mansson, A. H. Karlsson, and A. Andren. 2006. Effect of protein composition on the cheesemaking properties of milk from individual dairy cows. J. Dairy Sci. 89:3296-3305. 